\title{
Assessment of metal and metalloid contamination in the waters and stream sediments around the abandoned uranium mine area from Mortórios, central Portugal
}

\author{
A.M.R. Neiva ${ }^{\mathrm{a}, \mathrm{b}, *}$, P.C.S. Carvalho ${ }^{\mathrm{c}}$, I.M.H.R. Antunes ${ }^{\mathrm{d}}$, M.T.D. Albuquerque ${ }^{\mathrm{e}}$, A.C.S. Santos ${ }^{\mathrm{a}, \mathrm{b}}$, \\ P.P. Cunha ${ }^{\mathrm{c}, \mathrm{b}}$, S.B.A. Henriques ${ }^{\mathrm{a}, \mathrm{f}}$

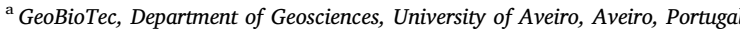 \\ ${ }^{\mathrm{b}}$ Department of Earth Sciences, University of Coimbra, Coimbra, Portugal \\ ${ }^{\mathrm{c}}$ MARE - Marine and Environmental Science Centre, University of Coimbra, Coimbra, Portugal \\ d ICT Centre, University of Minho, Braga, Portugal \\ ${ }^{\mathrm{e}}$ Instituto Politécnico de Castelo Branco, Castelo Branco, Portugal \\ ${ }^{\mathrm{f}}$ Laboratório Nacional de Energia e Geologia (LNEG), Alfragide, Portugal
}

\section{A R T I C L E I N F O}

\section{Keywords:}

Basic rock dykes

Abandoned uranium mines

Open pit lakes

Water

Sediments

Contaminations

\begin{abstract}
A B S T R A C T
In the abandoned Mortórios uranium mine area there are quartz veins containing wolframite and sulphides and basic rock dykes with torbernite and autunite cutting a porphyritic granite. The basic rock dykes were exploited and produced about $27 \mathrm{t}$ of $\mathrm{U}_{3} \mathrm{O}_{8}$, from 1982 to 1988 . There are an open pit lake and nine dumps. Surface water and groundwater are contaminated in $\mathrm{U}, \mathrm{As}, \mathrm{Cd}, \mathrm{Cr}, \mathrm{Cu}, \mathrm{Fe}, \mathrm{Mn}, \mathrm{Ni}$ and $\mathrm{Pb}$. Stream sediments are contaminated in $\mathrm{U}, \mathrm{As}$, Th and $\mathrm{W}$, which are adsorbed by smectite, kaolinite and iron- and aluminium- oxy-hydroxides. The maximum $U$ concentrations are of $1268 \mu \mathrm{g} / \mathrm{L}$ in the open pit lake, $100 \mu \mathrm{g} / \mathrm{L}$ in surface water, $103 \mu \mathrm{g} / \mathrm{L}$ in groundwater and $81.5 \mathrm{mg} / \mathrm{kg}$ in stream sediments all downstream of the open pit lake and dumps. Further downstream the $U$ concentration in water decreases, due to the high mobility of $U$ (VI), but the $U$ concentration in stream sediments increases. Calcium uranyl carbonate dominates in the open pit lake, but uranyl carbonate complexes dominate in surface water and groundwater. The maximum As concentrations are $56.0 \mu \mathrm{g} / \mathrm{L}$ in the open pit lake, $63.4 \mu \mathrm{g} / \mathrm{L}$ in the surface water and $66.7 \mu \mathrm{g} / \mathrm{L}$ in the groundwater, both downstream of the open pit lake and dumps. The arsenic occurs as As (V). The Mortórios area is compared with two other areas exploited from open pits, all located in the uranium-bearing Beira area of central Portugal. Vale de Abrutiga produced $90 \mathrm{t}$ of $\mathrm{U}_{3} \mathrm{O}_{8}$ between 1982 and 1989 and Mondego Sul produced $75 \mathrm{t}$ of $\mathrm{U}_{3} \mathrm{O}_{8}$ from 1987 to 1991 . The two mines consist of quartz veins containing sulphides, saleeite and meta-saleeite at Vale de Abrutiga and with sulphides, autunite, torbernite, meta-uranocircite and meta-saleeite at Mondego Sul cutting the Schist-graywacke Complex. The mine area of Vale de Abrutiga with the highest exploitation of $\mathrm{U}_{3} \mathrm{O}_{8}$ has strongly acidic to slight alkaline water, which is the most contaminated. Mortórios with the lowest exploitation presents a higher contamination of slightly acidic to alkaline water than that of acidic to alkaline water from Mondego Sul, but the former has As (V), whereas the latter has As (III), which is toxic. The stream sediments from Mortórios present the lowest contamination, except for Th that has a higher median value than that from Vale de Abrutiga. Stream sediments from Mondego Sul have higher $\mathrm{U}, \mathrm{Th}, \mathrm{Pb}$ and lower $\mathrm{Co}, \mathrm{Cr}, \mathrm{Cu}$ and $\mathrm{Zn}$ median values than those of Vale de Abrutiga.
\end{abstract}

\section{Introduction}

The countries that produced more uranium from 2005 to 2012, listed by increasing production, are China, USA, Uzbekistan, Russia, Namibia, Niger, Australia, Canada and Kazakhstan. Every year the production of uranium in these countries increased during that period
(Zammit et al., 2014). Since then, the production of uranium also increased every year due to the increase in nuclear power plants and the need for nuclear power (Selvakumar et al., 2018).

In western Europe, particularly in France, there are nearly 250 former uranium mine sites. Fifty of them are located in granitic massifs of the Limousin region (AREVA, 2004). Mineralogical and geochemical

\footnotetext{
* Corresponding author at: Department of Geosciences, University of Aveiro, Portugal.

E-mail address: neiva@dct.uc.pt (A.M.R. Neiva).
} 
transformations during incipient weathering at the surface of granitic rock piles from former uranium mines in Limousin from over a few decades were studied by Kanzari et al. (2017) showing that weathering products contributed to $\mathrm{U}(\mathrm{VI})$ stabilization under oxidizing conditions.

Uranium is radiologically and chemically toxic (Oughton et al., 2013). The biochemical toxicity of $U$ as a metal will cause risks arising to about six time orders of magnitude than those derived from its radioactivity (Milvy and Cothern, 1990). Exploration of uranium mines, ore treatments and leaching of uranium from open pits, underground mines and dumps going towards streams, sediments and soils are causing a significant contamination, which affects water, plants, animals and people. The abandoned uranium mine areas with relatively high concentrations of uranium pose some risk to ecosystems and human health. Uranium can enter through surface water, groundwater, soil-plant-animal interactions into the food chain.

Sixty radioactive deposits have been exploited for uranium and radium in Portugal between 1908 and 2001 (Carvalho, 2014). About $4370 \mathrm{t}$ of $\mathrm{U}_{3} \mathrm{O}_{8}$ were produced in the Uranium Portuguese Enterprise (ENU) building close to the old Urgeiriça mine (Carvalho, 2015). Most of the mine areas included exploitation, deposition of ores and ore treatment. They are mainly located in the uranium-bearing Beira area, in central Portugal (Carvalho et al., 2010). When those mine areas were closed down they were abandoned. Later, twenty three of them were remediated (EDM, 2017). In the uranium mine areas that were not remediated there are dumps containing tailings, waste rocks and accumulated leach residues. Some of them also have open pit lakes, but others were exploited underground.

This study presents an assessment of the contamination produced by the abandoned Mortórios uranium mine area and open pit lake and dumps on surface water, groundwater and stream sediments after the mine was closed down in 1988. The contamination of this abandoned mine area is compared with those produced by two other abandoned Portuguese uranium areas, before remediation, but each one containing an open pit lake.

\section{Geology, mineralization and mine site}

The Iberian Massif corresponds to the south-western extension of the European Variscan Belt. The Mortórios uranium mine area is located in the Central Iberian Zone, which is the innermost zone of the Iberian Massif (e.g. Farias et al., 1987). This zone is one of the largest segments of the European Variscan Belt. The Mortórios uranium mine area is located in the uranium-bearing Beira area of central Portugal, in the Guarda county, between the Marialva and Carvalhal villages, at about $3 \mathrm{~km} \mathrm{NE}$ of the later village (Fig. 1a, b). Three granites occur in the area and intruded the Douro-Beiras Supergroup (Schist-graywacke Complex), which corresponds to a thick and relatively monotonous sequence of phyllites and metagraywackes (Oliveira et al., 1992a). The Douro-Beiras Supergroup of Ediacaran to Cambrian age (e.g. Pereira et al., 2012; Dias da Silva et al., 2014) was intruded by a syn- $\mathrm{D}_{3}$ gneissic granite and a syn- $\mathrm{D}_{3}$ coarse-grained porphyritic granite (Fig. 1b). The latter granite was intruded by the late- to post-monzonitic granite (Fig. 1b). The syn-D3 granites have an emplacement age between 320 and $310 \mathrm{Ma}$ and the late- to post- $\mathrm{D}_{3}$ granites are 310-290 Ma (e.g. Ferreira et al., 1987; Azevedo and Aguado, 2013). The porphyritic granite is cut by small quartz veins, which contain wolframite, pyrrhotite, arsenopyrite, pyrite and chalcopyrite (JEN, 1959) and also by later basic rock dykes, probably dolerite, $\mathrm{N} 30^{\circ} \mathrm{E}, 60^{\circ} \mathrm{NW}$ to $70^{\circ} \mathrm{SE}$ of 0.1 to $14 \mathrm{~m}$ thick (Fig. 1b). The weathered basic rock dykes contain torbernite $\mathrm{Cu}\left(\mathrm{UO}_{2}\right)_{2}\left(\mathrm{PO}_{4}\right)_{2} \cdot 8-12\left(\mathrm{H}_{2} \mathrm{O}\right)$ and autunite $\mathrm{CaUO}_{2}\left(\mathrm{PO}_{4}\right)_{2} \cdot 10-12\left(\mathrm{H}_{2} \mathrm{O}\right)$. In general, the uranium mineralized area was $470 \mathrm{~m}$ long.

The Mortórios uranium mine was exploited by the Empresa Nacional de Urânio (ENU, SA) at the surface in six mineralized pockets with several levels each of $3 \mathrm{~m}$ and slopes of $60^{\circ}$ to an average depth of $40 \mathrm{~m}$ and with a mean of $0.18 \mathrm{U}_{3} \mathrm{O}_{8}$ content. About $4.5 \mathrm{t}$ of uranium were exploited every year from 1982 to 1988 (Fortes et al., 2001). There is an open pit lake of $250 \mathrm{~m}$ long, $80 \mathrm{~m}$ wide and $20 \mathrm{~m}$ deep containing about $126,800 \mathrm{~m}^{3}$ of water mainly accumulated by rainfall (Fig. 1c). Mud is deposited at the bottom of the lake. One dump of $24,229 \mathrm{~m}^{3}$ has a low uranium content and pine trees grew on the top. Three dumps consist of sterile waste and correspond to a total of 23,769 $\mathrm{m}^{3}$. There are other five dumps corresponding to a total volume of $87,734 \mathrm{~m}^{3}$ with unknown content, one of them is $20 \mathrm{~m}$ high (Quintela, 2015). Some dumps at West of the road were used to get sand and materials for roads and buildings (Madruga et al., 2010). The Marialva stream runs from SW to NE, is $<100 \mathrm{~m}$ far from the dumps, and most likely received discharge of waste water from the mining operations and at present receives surface drainage from the dumps during rainfalls.

In the Mortórios area the altitudes range from $650 \mathrm{~m}$ upstream the open pit lake and dumps and decrease to $490 \mathrm{~m}$ downstream, close to the Marialva village (IGE, 1994). This area is characterized by a warm and temperate climate with a Csb type, according to the Köppen and Geiger classification (IPMA, 2018). The average annual precipitation was $63 \mathrm{~mm}$ in 2014 and $33 \mathrm{~mm}$ in 2015. The rainfall dominates during the wet season reaching the highest values in January of 2014 $(150 \mathrm{~mm})$ and in October of $2015(100 \mathrm{~mm})$, while the lowest values are observed in August $2014(5 \mathrm{~mm})$ and July of $2015(1 \mathrm{~mm})$. The average temperature ranged from $4{ }^{\circ} \mathrm{C}$ (February 2014) to $24^{\circ} \mathrm{C}$ (July 2015) (IPMA, 2014, 2015).

The area has rural characteristics with vegetation that is dense and mainly with herbaceous species. The most dominant species are Castanea sativa, Quercurs pyrenaica, Ulmus minor, Prunus avium, Olea europaea var. europaea, Pistacia terebinthus, Fraxinus angustifólia subsp. Angustifólia, Erica arbórea, Sambucus nigra, Crataegus monogyna, Pynus pinaster, Frangula alnus, Alnus glutinosa, Salix atrocinerea, Quercus rotundifólia and Quercus suber trees. The herbaceous species consist of Genista cinerascens, Leucanthemopsis pulverulenta, Rubus henriquesii, Echinospartum ibericum, Dianthus lusitanus, Erysimum linifolium, Halimium umbellatum var. viscosum, Biscutella valentina subsp. Valentina, Cytisus stiatus, Cistus psilosepalus, Ulex minor and Pterospartum tridentatum subsp. Cantabricum (Araújo et al., 2018). Around the abandoned mine, small agricultural areas occur with potato crops, vineyards and pastures, which are irrigated by the Marialva stream and wells located in the stream margins.

\section{Water and stream sediment samples and analytical methods}

Seventy water samples were collected in a total of twenty one water sampling points of the abandoned Mortórios uranium mine area during a hydrological year, because occasionally some points were dry. Eleven sampling points are from the Marialva stream, two others are from the open pit lake and eight others are from wells (Fig. 1c). They were collected in spring (April 2014), autumn (October 2014), winter (February 2015) and summer (July 2015). Waters from the Marialva stream and the open pit lake were collected as possible about $20 \mathrm{~cm}$ below the surface of the water level. Those from wells were collected between 1 and $2 \mathrm{~m}$ below the groundwater level. The $\mathrm{pH}$, oxidation-reduction potential (ORP), electrical conductivity (EC), temperature (T) and dissolved oxygen (DO) were measured in situ using a multi element equipment of Hanna Instruments. The alkalinity $\left(\mathrm{HCO}_{3}{ }^{-}\right)$was measured according to the method of Brown et al. (1970). The Eh is the ORP result +209 according to the $\mathrm{Ag}: \mathrm{AgCl}$ electrode used as a reference, assuming $T=15^{\circ} \mathrm{C}$ (Nordstrom and Wilde, 2005). The samples were transported in polypropylene bottles within thermic arks to the Department of Earth Sciences, University of Coimbra, Portugal. The samples were filtered through $0.45 \mu \mathrm{m}$ pore size membrane filters. Total dissolved solids (TDS) and total solids (TS) were determined after evaporation of $100 \mathrm{~mL}$ of filtered and unfiltered water through $0.45 \mu \mathrm{m}$ filters, respectively. Anions were determined in non-acidified water samples by ion chromatography with a Dionex ICS 3000 Model. Cations 

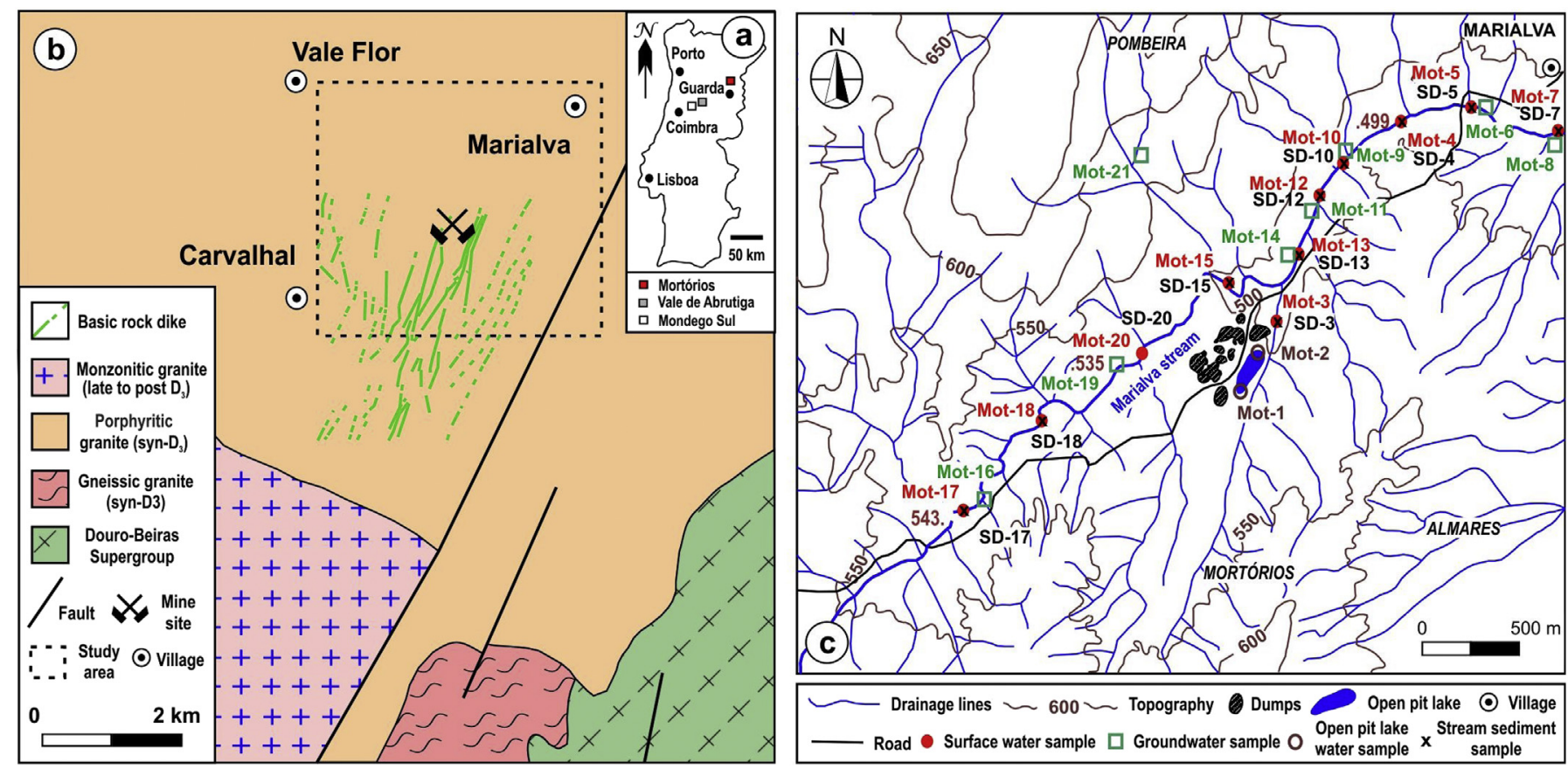

Fig. 1. Mortórios uranium mine area and collected water and stream sediment samples. a) Location of the study area and two other U-mine areas in the map of Portugal; b) Geological map and delimitation of the Mortórios area (adapted from Oliveira et al., 1992b and Jen, 1959); c) Location of the open pit lake, dumps and water and stream sediment samples from Mortórios on the topographic map (adapted from IGE, 1994).

were determined in water samples acidified with $\mathrm{HNO}_{3}$ at $\mathrm{pH} 2$ by Inductively Coupled Plasma Optical Emission Spectrometry (ICP-OES), using a Horiba Jovin Yvon JY2000 2 spectrometer with a monochromator. A laboratory water standard, duplicate blanks and the repetition of a water sample were analysed in each group of twenty one water samples for quality control. The detection limits of metals and metalloids are given in Appendix A. The precision was better than 5\%, but was of 6\% for $\mathrm{Pb}, \mathrm{Sr}$ and $\mathrm{U}$ of samples collected in April 2014, $\mathrm{NO}_{3}{ }^{-}$ and As of samples collected in October 2014 and Ba of samples collected in July 2015 and $7 \%$ for $\mathrm{Cl}^{-}$and $\mathrm{Li}$ in samples collected in April 2014. The ion balance errors from the most analytical data are better than $\pm 10 \%$, but six groundwater samples presented values from -16 to $-27 \%$, mainly due to lower $\Sigma$ cations than $\Sigma$ anions. The ion balance errors can be accepted up to $30 \%$ if the conductivity of water is lower than $50 \mu \mathrm{S} / \mathrm{cm}$ (Custódio and Llamas, 2001), as occurs in most of these six analysed samples (Appendix A). Furthermore, the TDS values of these six samples are low indicating low positive charge depletion (Mathew and Samant, 2014).

A total of ten samples of stream sediments were collected in the 29th of April 2014. Two of them are from upstream of the open pit lake and dumps, but the other eight samples are from more progressively downstream locations of the open pit lake and dumps (Fig. 1c). Some of them received significant surface drainage from the open pit lake and dumps (SD3, Fig. 1c). The samples were transported in polyethylene bags to the laboratory and dried at $40{ }^{\circ} \mathrm{C}$. Later they were easily disaggregated with a silicone hammer and they were sieved through $2 \mathrm{~mm}$ and $250 \mu \mathrm{m}$ sieves for different determinations. The grain size and textural characteristics were determined in the stream sediment samples with the highest $U$ and Th concentrations. For determining the grain-size distribution of each sediment sample, the percentages of gravel ( $>2 \mathrm{~mm})$, sand $(2 \mathrm{~mm}-63 \mu \mathrm{m})$, silt $(63-4 \mu \mathrm{m})$ and clay $(<4 \mu \mathrm{m})$ were obtained through integration of two methods: by sieving the fraction $>63 \mu \mathrm{m}$; and by laser diffraction analysis of the fraction $<$ $63 \mu \mathrm{m}$, with a Coulter laser granulometer $(2 \mathrm{~mm}-0.04 \mu \mathrm{m}$; precision up to $2 \%$ ). A Philips PW 3710 X-ray diffractometer, with a $\mathrm{Cu}$ tube, at $40 \mathrm{kV}$ and $20 \mathrm{nA}$ was used for the mineralogical identifications. The mineralogical composition of the $<2 \mu \mathrm{m}$ fraction was obtained in oriented samples before and after heating up to $550^{\circ} \mathrm{C}$ and with ethylene glycol treatment. The percentages of the clay minerals of each sample were determined through the peak areas of the mineral present, with the use of specific correction parameters. The $\mathrm{pH}$ was measured in a solid-water suspension (liquid/solid ratio of 2.5) and the British standard BS (1995a) was used. Electrical conductivity (EC) was measured in a liquid/solid ratio of $1 / 5$ and the British standard BS (1995b) was applied. The chemical analyses of metals and metalloids were determined in stream sediment samples $<250 \mu \mathrm{m}$, which were digested with aqua regia ( $\left.3: 1 \mathrm{HCl}-\mathrm{HNO}_{3}\right)$, filtered through a $2 \mu \mathrm{m}$ pore size filter and analysed by Inductively Coupled Plasma Optical Emission Spectroscopy, ICP-OES of Horiba Jovin Yvon, model YV 20002 spectrometer with a monochromator. Duplicate blanks and a laboratory standard were included and their data were obtained at the beginning and the end of determinations. An in-house soil, prepared with aqua regia analysis, was validated using the certified sewage sludge amended soil BCR $143 \mathrm{R}$. The precision of determinations was better than $4 \%$. The conversions of the detection limit from $\mathrm{mg} / \mathrm{L}$ to $\mathrm{mg} / \mathrm{kg}$ were estimated using the following equation DL $(\mathrm{mg} / \mathrm{kg})=\left(\mathrm{X}^{*} 0.1\right) / \mathrm{m}$, where $\mathrm{X}$ is the $\mathrm{DL}$ at $(\mathrm{mg} / \mathrm{L})$ given by the ICP-OES and $\mathrm{m}$ is the average of heavy masses of the samples in $\mathrm{kg}$. All determinations in water and stream sediment samples were carried out in the Department of Earth Sciences, University of Coimbra, Portugal. The modelling of $\mathrm{As}, \mathrm{Pb}$, Th and $\mathrm{U}$ in water samples with the highest concentrations of these elements was carried out using the software Phreeq $\mathrm{C}$ and the ThermoChimie database (Andra, 2009; Parkhurst and Appelo, 2013).

Organic matter (OM) and cation exchange capacity (CEC) were determined in five representative stream sediment samples, two from upstream and three from downstream of the open pit lake and dumps and providing the highest $\mathrm{U}$ and Th concentrations. The organic carbon content was determined using an elemental analyzer. $\mathrm{CO}_{2}$ was quantified by an NIRD (near infrared detector), after oxidation at $100{ }^{\circ} \mathrm{C}$, and $\mathrm{CO}_{2}$ was converted into C. Assuming that OM contains $58 \%$ organic carbon (Nelson and Sommers, 1996), the organic matter (OM) was calculated using a factor of 1.724 for the C. The precision was of $3.6 \%$. The CEC was determined according to the methods of Thomas (1982). It is the sum of extractable bases and extractable acidity by the 


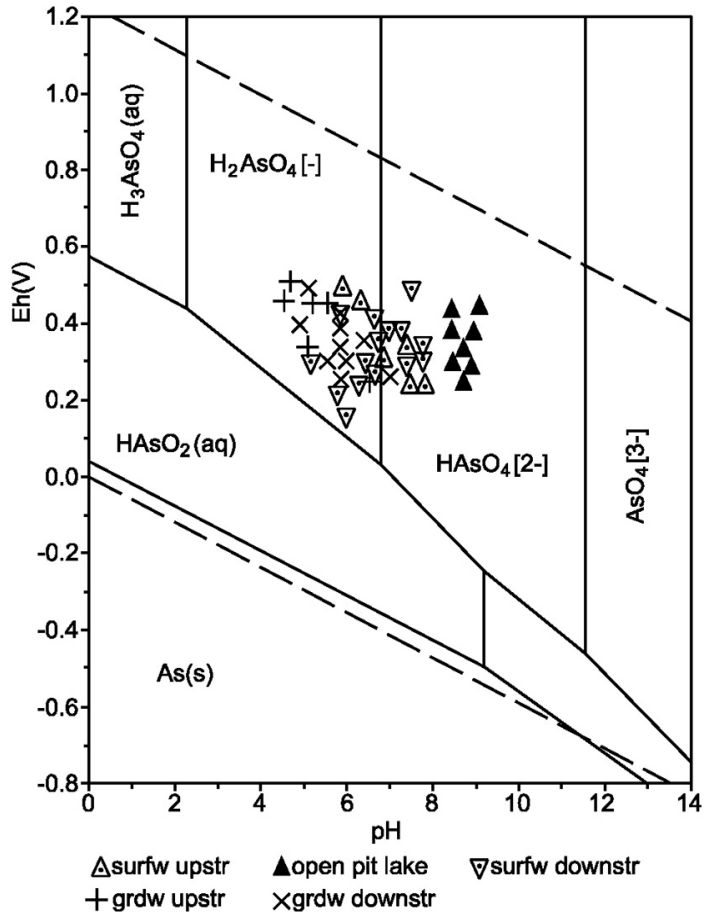

Fig. 2. Eh - pH values for the system As-Fe-O-H-S of the waters from the abandoned Mortórios uranium mine area. Adapted from GSJ (2005). surfw upstr - surface water from upstream of the open pit lake and dumps; surfw downstr - surface water from downstream of the open pit lake and dumps; grdw upstr - groundwater from upstream the open pit lake and dumps; grdw downstr - groundwater from downstream of the open pit lake and dumps.

ammonium acetate solution ( $\mathrm{pH} 7)$, with a precision of $1.2 \%$. These determinations were carried out at the Department of Soils and Plants, University of Trás-os-Montes and Alto Douro (UTAD), Portugal.

\section{Results}

\subsection{Waters}

The physical-chemical parameters and chemical results of water samples from the abandoned Mortórios uranium mine area are given in Appendix A. The surface water samples Mot-17 st, 18 st and 20 st and the groundwater samples Mot- $21 \mathrm{w}, 16 \mathrm{w}$ and $19 \mathrm{w}$ are the representatives of the background or natural level, because they are located upstream of the open pit lake and dumps (Fig. 1c). However, the studied area is located downstream of two other abandoned uranium mine areas. According to the Piper classification, most of the studied water samples are of non-dominant-bicarbonate type. Some surface water samples ( 17 st, 20 st, 3 st, 15 st, 13 st, 4 st and 7 st) and samples from two wells (16 w and $6 \mathrm{w}$ ) are magnesium-bicarbonate type or magnesium-non-dominant type. Water samples collected in July from the open pit lake (1op and $2 \mathrm{op}$ ) and from the closest well (14 w) to this lake and dumps (Fig. 1c) are non-dominant sulphate type. The $\mathrm{pH}$ of the open pit lake has higher values, ranging from 8.42 to 9.23 , than samples from the surface water, with 5.29-7.93 values, and groundwater samples, with $\mathrm{pH}$ values ranging from 4.59 to 7.23 . The Eh values range from 125 to $495 \mathrm{mV}$. The water samples were plotted in the Eh-pH diagram (Fig. 2). Waters from the open pit lake fall in the $\mathrm{HAsO}_{4}[2-]$ field, because they have the highest $\mathrm{pH}$ values. Most of the other surface waters and also groundwaters fall in the $\mathrm{H}_{2} \mathrm{AsO}_{4}[-]$ field. The electrical conductivity $(\mathrm{EC})$ of the surface water samples ranges from 32 to $72 \mu \mathrm{S} / \mathrm{cm}$, showing that they are poorly mineralized, which is supported by the total dissolved solids (TDS), ranging from 15 to $66 \mathrm{mg} / \mathrm{L}$. The open pit lake has higher EC values, of $263-415 \mu \mathrm{S} / \mathrm{cm}$, and TDS values, of $206-244 \mathrm{mg} / \mathrm{L}$, than surface water and groundwater (Appendix A), indicative of some mineralization. In the surface water, the dissolved oxygen (DO) showed the lowest value of $0.00 \mathrm{mg} / \mathrm{L}$ in summer and the highest value of $11.29 \mathrm{mg} / \mathrm{L}$ in winter. The comparison of the surface water values from samples collected upstream and downstream of the open pit lake and dumps shows that the latter presents the highest Eh, EC and TDS values. Groundwater downstream of the open pit lake and dumps has the highest values of $\mathrm{pH}, \mathrm{EC}$ and DO compared with the upstream groundwater (Appendix A). Groundwaters reach the lowest $\mathrm{pH}$ value and the highest Eh, EC and TDS values compared with the surface waters.

In general, $\mathrm{SO}_{4}{ }^{2-}, \mathrm{Al}, \mathrm{B}, \mathrm{Ba}, \mathrm{Cd}, \mathrm{Co}, \mathrm{Cr}, \mathrm{Cu}, \mathrm{Mn}, \mathrm{Li}, \mathrm{Ni}, \mathrm{Pb}, \mathrm{Sr}$ and $\mathrm{Zn}$ present higher concentrations in April 2014, but Th and $\mathrm{U}$ show higher concentrations in February 2015 (Figs. 3a, b; 4a, b; Appendix A). However, the highest concentration of $\mathrm{U}$ was found in the open pit lake in April 2014 (Fig. 3b) when the pH had its highest value. The open pit lake has higher $\mathrm{F}^{-}, \mathrm{SO}_{4}{ }^{2-}, \mathrm{HCO}_{3}{ }^{-}, \mathrm{Na}, \mathrm{K}, \mathrm{Ca}, \mathrm{Mg}, \mathrm{Li}$ and $\mathrm{U}$ concentrations than the surface water upstream and downstream of this lake and dumps (Appendix A; Fig. 3a, b). The U concentration of the open pit lake ranges between 1004 and $1268 \mu \mathrm{g} / \mathrm{L}$. The highest concentrations of $\mathrm{B}, \mathrm{Cd}, \mathrm{Cr}, \mathrm{Ni}, \mathrm{Pb}, \mathrm{Sr}$ and $\mathrm{Zn}$ were also reached in the open pit lake. The surface waters from upstream and downstream of the open pit lake and dumps were compared and showed that the highest concentrations of $\mathrm{NO}_{2}{ }^{-}, \mathrm{SO}_{4}{ }^{2-}, \mathrm{NO}_{3}{ }^{-}, \mathrm{PO}_{4}{ }^{3-}, \mathrm{HCO}_{3}{ }^{-}, \mathrm{K}, \mathrm{Ca}, \mathrm{Mg}, \mathrm{Al}, \mathrm{B}$, $\mathrm{Cr}, \mathrm{Li}, \mathrm{Mn}, \mathrm{Zn}, \mathrm{As}$, Th and $\mathrm{U}$ tend to occur in the downstream surface water, but the highest concentration of Fe occurs in the upstream surface water (Appendix A; Fig. 3). The groundwater presents the highest concentrations of $\mathrm{F}^{-}, \mathrm{SO}_{4}{ }^{2-}, \mathrm{NO}_{3}{ }^{-}, \mathrm{PO}_{4}{ }^{3-}, \mathrm{HCO}_{3}{ }^{-}, \mathrm{K}, \mathrm{Ca}, \mathrm{Mg}, \mathrm{Al}, \mathrm{Cd}$, $\mathrm{Sr}$ and $\mathrm{U}(103 \mu \mathrm{g} / \mathrm{L})$ downstream of the open pit lake and dumps, but the highest concentrations of $\mathrm{B}, \mathrm{Fe}, \mathrm{Li}, \mathrm{Mn}, \mathrm{Pb}, \mathrm{Zn}$, As and Th occur upstream (Appendix A; Fig. 4). Groundwater and surface water, both downstream of the open pit lake and dumps were compared. The former has the highest concentrations of $\mathrm{F}^{-}, \mathrm{SO}_{4}{ }^{2-}, \mathrm{NO}_{3}{ }^{-}, \mathrm{PO}_{4}{ }^{3-}$, $\mathrm{HCO}_{3}{ }^{-}, \mathrm{K}, \mathrm{Ca}, \mathrm{Mg}, \mathrm{Al}, \mathrm{B}, \mathrm{Ba}, \mathrm{Cd}, \mathrm{Mn}, \mathrm{Sr}, \mathrm{Zn}, \mathrm{As}$, Th and U (Appendix A; Figs. 3, 4), but the latter presents the highest concentration of Fe. The open pit lake has higher $\mathrm{F}^{-}, \mathrm{SO}_{4}{ }^{2-}, \mathrm{HCO}_{3}{ }^{-}, \mathrm{Na}, \mathrm{Ca}, \mathrm{Mg}, \mathrm{Li}$ and $\mathrm{U}$ concentrations than the groundwater downstream the open pit lake and dumps (Appendix A; Figs. 3a, b; 4a, b).

\subsection{Stream sediments}

The textural characteristics, physical-chemical parameters and concentrations of metals and metalloids in stream sediment samples collected from the abandoned Mortórios uranium mine area are given in Table 1. In general, they are dominated by sand with values of $63 \%$ (only two samples) and 10-97\% from upstream and downstream of the open pit lake and dumps, respectively. Five samples from the latter area consist mainly of $68-90 \%$ of gravel (Table 1). The gravel fraction ( $>2 \mathrm{~mm}$ ) is always dominated by small pebbles $(4-2 \mathrm{~mm})$. Values of $0.13-0.27 \%$ of silt and $0.83-1.31 \%$ of clay were provided by upstream samples and values of $0.07-3.14 \%$ of silt and $0.00-1.26 \%$ of clay are from samples located downstream of the open pit lake and dumps. The clast composition of the sediment samples consists mainly of granite, but also of quartz and feldspars (K-feldspar and plagioclase) with accessory muscovite, biotite, phyllite and clay minerals. Identification and semi-quantification of clay minerals in the fraction $<2 \mu \mathrm{m}$ provided the following mineralogy: kaolinite (9-53\%), illite (25-39\%), smectite (3-31\%), chlorite (30-46\%) and vermiculite (9-13\%). Higher contents of smectite, chlorite and vermiculite occur downstream of the open pit lake and dumps. Some stream sediments from downstream of the open pit lake and dumps present the lowest $\mathrm{pH}$ values of 5.38-5.51 (Table 1). However, the other stream sediments from this area have $\mathrm{pH}$ values of 6.63-6.90 and those from upstream of the open pit lake and dumps are of $6.50-6.92$. The highest values of EC $(61 \mu \mathrm{S} / \mathrm{cm})$ and CEC $(3.8 \mathrm{cmol} / \mathrm{kg}$ ) are reached downstream of the open pit lake and dumps, but they are very low. Aluminium, Fe, Co, Cr, Cu, Ni, Pb, Sr, W and Zn 

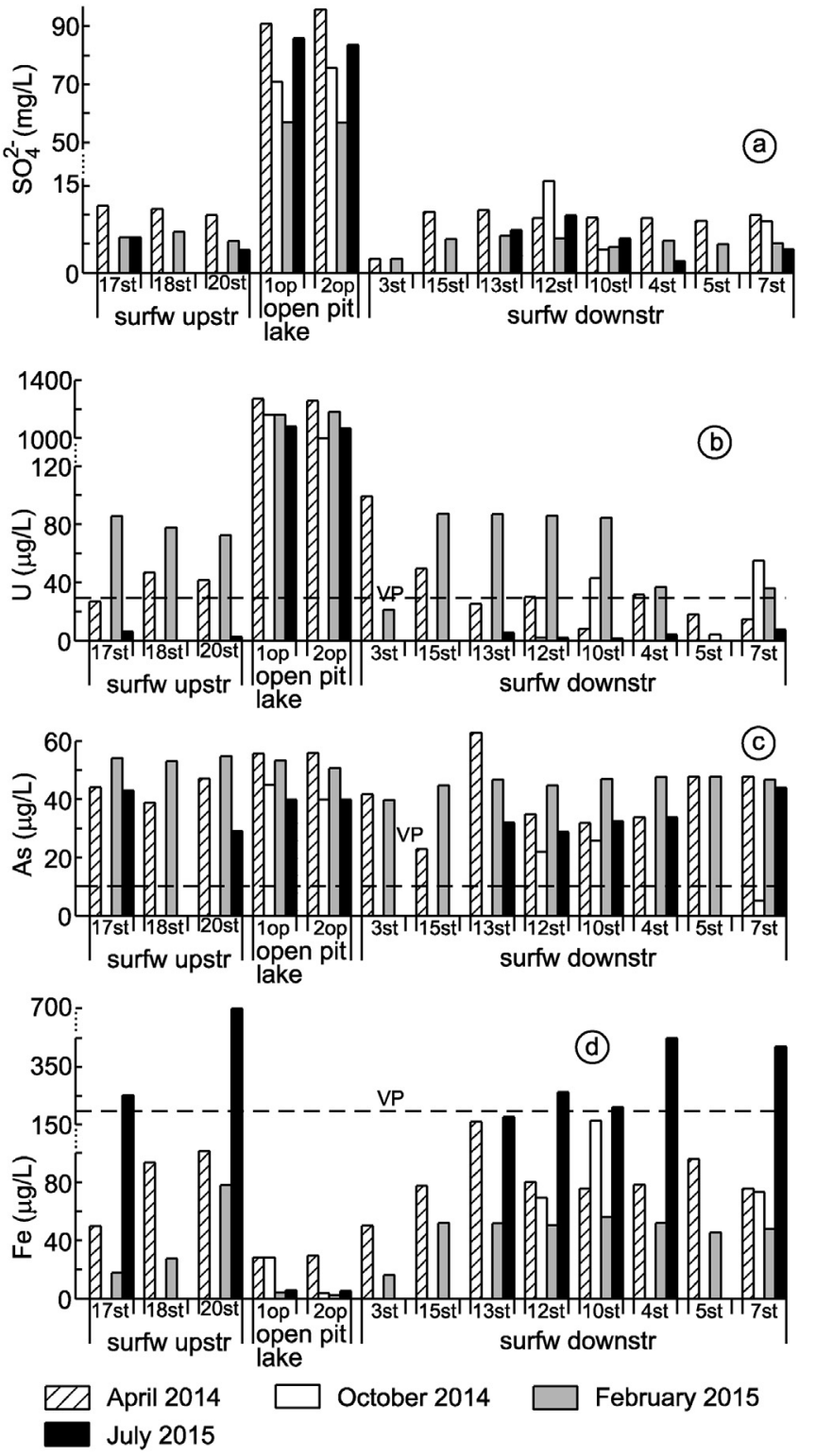

Fig. 3. Seasonal variations in $\mathrm{SO}_{4}{ }^{2-}$ and some trace elements from surface waters and open pit lake of the abandoned Mortórios uranium mine area. surf upstr and surf downstr as in Fig. 2. VP- permitted values for drinking water (UWHO, 2017; As and Fe- Portuguese decrees, 1998, 2007, 2017).

concentrations in the stream sediments present the same trend downstream of the open pit lake and dumps (Table 1), showing slight decreases downstream. In general, stream sediments from downstream of the open pit lake and dumps have higher Mn and $\mathrm{U}$ concentrations than stream sediments from upstream locations (Table 1, Fig. 5). The highest concentrations of $\mathrm{Al}, \mathrm{Fe}, \mathrm{As}, \mathrm{Co}, \mathrm{Cr}, \mathrm{Mn}, \mathrm{Ni}, \mathrm{Sr}, \mathrm{Th}, \mathrm{U}, \mathrm{W}$ and $\mathrm{Zn}$ occur downstream of the open pit lake and dumps.

\section{Discussion}

\subsection{Geochemistry of waters}

The $\mathrm{pH}$ of the open pit lake is alkaline ranging from 8.42 to 9.23 , because new water has been added by rainfalls since 1988 with the drainage resulting from the weathering of basic rock dykes and also a probable addition of lime $\mathrm{Ca}(\mathrm{OH})_{2}$ by the EDM. Surface water and groundwater samples are slightly acidic to alkaline with $\mathrm{pH}$ values of 5.29-7.93 and 4.59-7.23, respectively. The acidic values are attributed
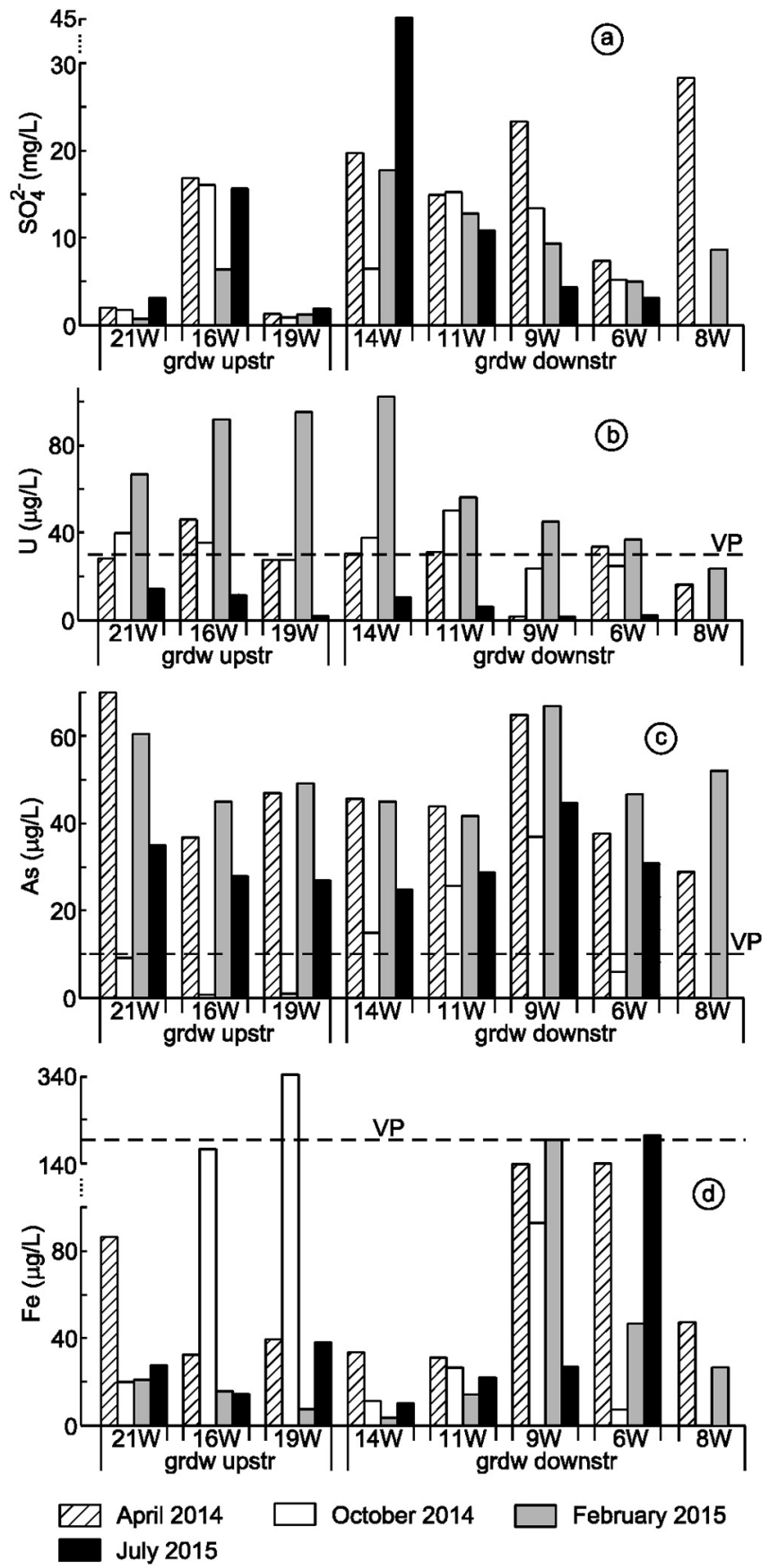

Fig. 4. Seasonal variation in $\mathrm{SO}_{4}{ }^{2-}$ and some trace elements from groudwaters of the abandoned Mortórios uranium mine area. grdw upstr and grdw downstr as in Fig. 2. VP as in Fig. 3.

to oxidation of sulphides from quartz veins. Neutral to alkaline $\mathrm{pH}$ values are typical of waters close to uranium mines (e.g. Gómez et al., 2006; Neiva et al., 2014, 2015, 2016a). The open pit lake has higher EC values $263-415 \mu \mathrm{S} / \mathrm{cm}$ than the highest values of the surface water and groundwater of $72 \mu \mathrm{S} / \mathrm{cm}$ and $133 \mu \mathrm{S} / \mathrm{cm}$, respectively, both from downstream of the open pit lake and dumps, because the open pit lake received the direct effect of weathering of sulphides from quartz veins and uranium minerals (torbernite and autunite) from basic rock dykes.

There is not always a significant distinction between the concentrations of the same metal and also the metalloid in surface water from upstream and downstream of the open pit lake and dumps. The same happens for groundwater. This is attributed to the contamination provided by the uranium mine areas of A-do-Cavalo (at $5 \mathrm{~km}$ ) and 

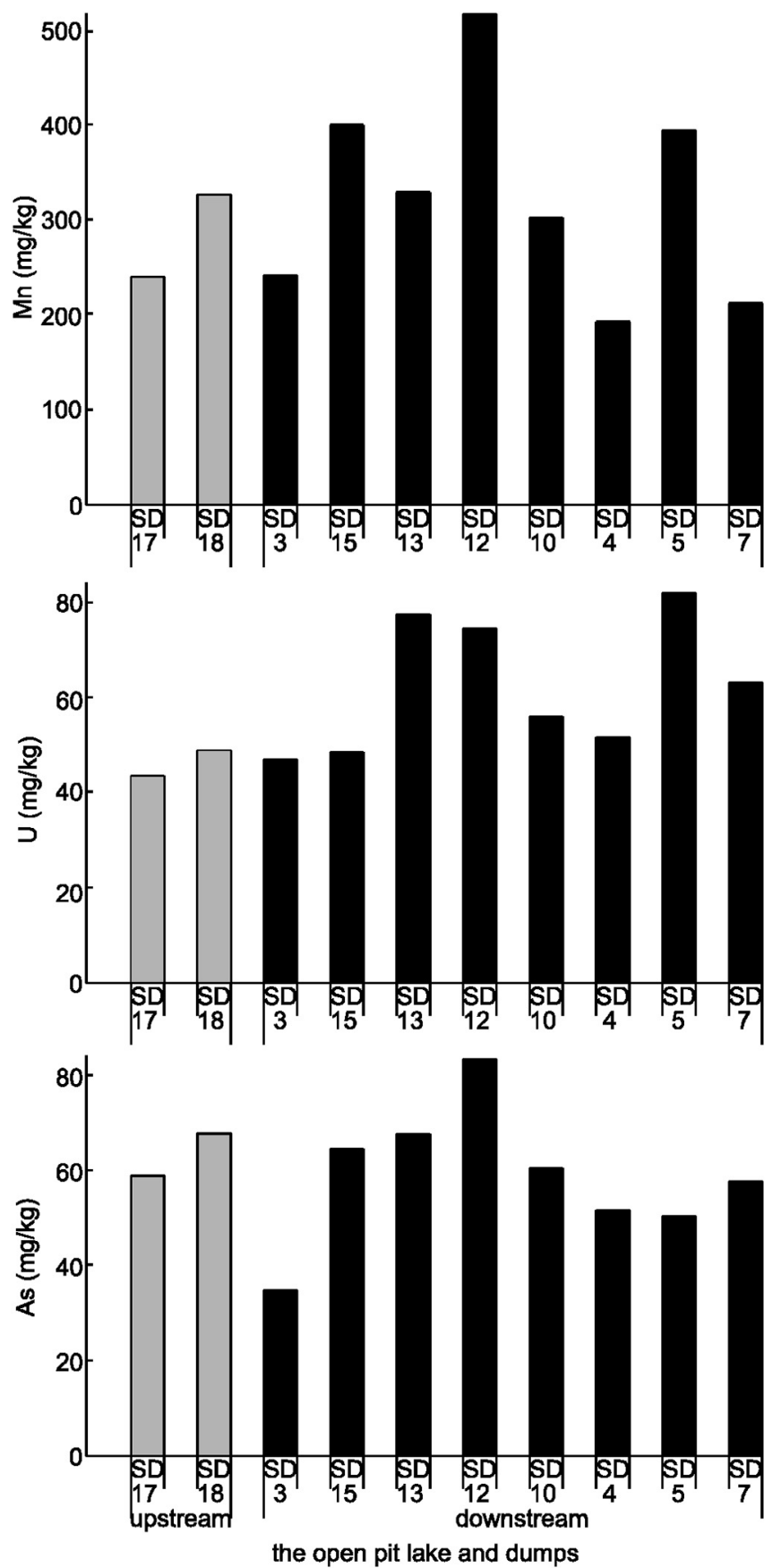

Fig. 5. Diagrams of $\mathrm{Mn}, \mathrm{U}$ and As of stream sediments from the abandoned Mortórios uranium mine area.

Quinta das Vermelhas (at $2.8 \mathrm{~km}$ ) both located upstream of the studied area. The consequence is the difficulty of obtaining a background resulting from a pristine U-mineralization (without contributions by anthropic works).

Most of the surface water samples collected in February 2015 do not contain $\mathrm{Al}, \mathrm{B}, \mathrm{Ba}, \mathrm{Cd}, \mathrm{Co}, \mathrm{Cr}, \mathrm{Cu}, \mathrm{Li}, \mathrm{Ni}, \mathrm{Pb}, \mathrm{Sr}$ and $\mathrm{Zn}$ attributed to their higher $\mathrm{pH}$ values, ranging from 6.81 to 7.93 , as the formation of secondary minerals such as hydroxides and oxyhydroxides is favoured (Jambor, 1994). This effect is lower in groundwater, where the $\mathrm{pH}$ values are of 5.89-7.23 and due to the dilution caused by the rainfall. The open pit lake has higher $\mathrm{pH}$, EC and TDS values and higher $\mathrm{F}^{-}$, $\mathrm{SO}_{4}{ }^{2-}, \mathrm{HCO}_{3}{ }^{-}, \mathrm{Na}, \mathrm{Ca}, \mathrm{Mg}, \mathrm{Li}$ and $\mathrm{U}$ concentrations than surface water and groundwater downstream of the open pit lake and dumps (Appendix A; Figs. 3a, b; 4a, b) due to the higher concentration of water 
and weathering of sulphides from quartz veins and torbernite and autunite from the basic rock dykes. However, the high $\mathrm{pH}$ values and $\mathrm{Ca}$ concentration in the open pit lake is attributed to the weathering of basic rock dykes and a probable addition of lime $\mathrm{Ca}(\mathrm{OH})_{2}$ by the EDM. The groundwater downstream of the open pit lake and dumps has slightly higher $\mathrm{F}^{-}, \mathrm{SO}_{4}{ }^{2-}, \mathrm{NO}_{3}{ }^{-}, \mathrm{PO}_{4}{ }^{3-}, \mathrm{HCO}_{3}{ }^{-}, \mathrm{K}, \mathrm{Ca}, \mathrm{Mg}, \mathrm{Al}, \mathrm{B}, \mathrm{Ba}$, $\mathrm{Cd}, \mathrm{Mn}, \mathrm{Sr}, \mathrm{Zn}, \mathrm{As}$, Th and $\mathrm{U}$ concentrations than the surface water downstream of the open pit lake and dumps (Appendix A; Figs. 3a, b, c; $4 a, b, c)$, because groundwater causes higher weathering of sulphides from quartz veins and torbernite and autunite from basic rock dykes, also of the porphyritic granite.

The highest concentrations of $U$ in surface water and groundwater were reached in February 2015 (Appendix A, Figs. 3b, 4b) during the winter when the flow was higher and leaching from basic rock dykes took place, as it also occurred in uranium mine areas containing quartz veins with uranium minerals (e.g. Pinto et al., 2004; Neiva et al., 2014, 2015, 2016a). However, at the open pit lake the highest U concentration was reached in April 2014, when most of the water was accumulated and leaching from rocks was the highest. The dissolution of torbernite and autunite causes the oxidation of U(IV) producing $\mathrm{U}(\mathrm{VI})$ and formation of strong complexes with the anions $\mathrm{OH}^{-}, \mathrm{F}^{-}, \mathrm{Cl}^{-}, \mathrm{CO}_{3}{ }^{2-}$, $\mathrm{SO}_{4}{ }^{2-}$ and $\mathrm{PO}_{4}{ }^{3-}$ (Langmuir, 1978) that increase the uranium mobility. Torbernite and autunite occur at Mortórios as secondary uranium minerals containing uranyl ions $\left(\mathrm{UO}_{2}{ }^{2+}\right)$, which are soluble and mobilized in the environment. The $\left(\mathrm{UO}_{2}{ }^{2+}\right)$ is the most stable under acidic or oxygenated conditions (Duff and Amrhein, 1996). Under neutral and alkaline $\mathrm{pH}$ conditions, the strong carbonate complexes $\mathrm{UO}_{2}\left(\mathrm{CO}_{3}\right)_{2}{ }^{2-}$ and $\mathrm{UO}_{2}\left(\mathrm{CO}_{3}\right)_{3}{ }^{4-}$ can be formed (Grenthe et al., 2003). Furthermore, alkaline earth uranyl carbonate species may also occur in neutral waters with significant carbonate species (Vercouter et al., 2015). The uranium mobility is decreased if uranyl ions are adsorbed into predominantly negatively charge surface sites (e.g. Barnett et al., 2000). The amount of clay minerals in stream sediments is moderate to low (Table 1). The uranium can be retained in kaolinite and smectite. In the fraction $<2$ $\mu \mathrm{m}$ it was found that smectite reaches $31 \%$ among clay minerals from stream sediments of downstream the open pit lake and dumps. The Th shows the highest concentration in water during the winter (February 2015). However, its concentration is lower than that of $U$ (Appendix A) as in all other studied Portuguese uranium mine areas (e.g. Pinto et al., 2004; Neiva et al., 2014, 2015, 2016a; Antunes et al., 2018), because Th compounds are hardly soluble and easily precipitated in solid phases (Tutu et al., 2009). In general, $\mathrm{SO}_{4}{ }^{2-}, \mathrm{B}, \mathrm{Ba}, \mathrm{Cd}, \mathrm{Co}, \mathrm{Cr}, \mathrm{Cu}, \mathrm{Mn}, \mathrm{Li}, \mathrm{Ni}$, $\mathrm{Pb}, \mathrm{Sr}$ and $\mathrm{Zn}$ show higher concentrations in April 2014, at the spring. A similar behaviour was found for $\mathrm{SO}_{4}{ }^{2-}$ and $\mathrm{Ni}$ in the Mondego Sul uranium mine area (Neiva et al., 2016a).

The Eh-pH diagram (Fig. 2) shows that under oxidizing conditions, the pentavalent As $(\mathrm{V})$ is present as aqueous complex $\left(\mathrm{HAsO}_{4}{ }^{2-}\right.$ and $\mathrm{HAsO}_{4}{ }^{-}$) in surface water and groundwater. The results of geochemical modelling show that As occurs as pentavalent species both in surface water and groundwater (Table 2), being the more easily adsorbed and less toxic form of arsenic. In some waters (mainly 1op and 2op samples) there is the formation of calcium-arsenate complexes $\mathrm{Ca}\left(\mathrm{HAsO}_{4}\right)$ and $\mathrm{Ca}$ $\left(\mathrm{AsO}_{4}{ }^{-}\right)$due to the alteration of autunite and a probable addition of lime $\mathrm{Ca}(\mathrm{OH})_{2}$ by the EDM. The formation of these complexes represents a minor proportion and due to the alkaline $\mathrm{pH}$ of these samples (1op and 2op) the arsenic tends to be in solution due to the reduction of oxyanions adsorption at these $\mathrm{pH}$ values. The saturation in ferrihydrite, goethite, hematite, maghemite and lepidocrocite in all water samples also suggests that some part of the arsenic can be adsorbed in these minerals, namely in samples with the lowest $\mathrm{pH}$ values (Panagiotaras and Nikolopoulos, 2015). The eventual change of redox conditions can lead to the Fe reduction, and therefore the As release to solution.

Lead occurs mainly in the divalent form (74.35 to $96.77 \%$ ) in surface waters and groundwaters (Table 2). However, in the waters samples 1op, 2op and $9 \mathrm{w}$, the $\mathrm{PbCO}_{3}$ can also be formed due to the high $\mathrm{HCO}_{3}{ }^{-}$content of these waters. The lower contribution of $\mathrm{SO}_{4}{ }^{2-}$ and
$\mathrm{pH}$ near neutral to alkaline reduces the formation of lead sulphate complex in these waters ( 0.90 to $4.46 \%)$.

Thorium occurs mainly as carbonate hydroxide species (Table 2). Thorium is less soluble than $\mathrm{U}$ in all conditions. In solution, the species $\mathrm{Th}(\mathrm{OH})_{4}$ and $\mathrm{Th}(\mathrm{OH})_{3}\left(\mathrm{CO}_{3}{ }^{-}\right)$form colloids or precipitates with iron and manganese oxyhydroxides (Kim et al., 2010). Furthermore, the Th precipitates if the $\mathrm{pH}$ increases to values above 5 (Langmuir and Herman, 1980) and the geochemical modelling indicates that all analysed waters are saturated in $\mathrm{ThO}_{2}$.

In surface water and groundwater from the abandoned Mortórios uranium mine area, of alkaline $\left(\mathrm{HCO}_{3}{ }^{-}\right)$type, uranyl-carbonate complexes are dominant (Table 2). However, the calcium uranyl carbonate complexes dominate in samples 1op and 2op (open pit lake), but also in 15 st and $14 \mathrm{w}$ (Table 2). This calcium uranyl carbonate complexes increase the mobility of uranium in waters, making it more soluble in oxidized environments (Fox et al., 2006) and decreasing its adsorption potential. This is the reason why acid, but also the alkaline oxygenated mine waters may carry a significant concentration of dissolved uranium (Lottermoser, 2010), which is the case of waters 1op and 2op from the abandoned Mortórios uranium mine area. The $\mathrm{pH}$ range and the dissolved $\mathrm{U}$ of these waters increase the $\mathrm{U}$ dispersion through infiltration and also by the spatial contamination of the surrounding surface waters (3 st, 13 st and 14 st). However, due to the saturation in secondary carbonate minerals like calcite, dolomite and aragonite (in water samples 1op and 2op), U may co-precipitate with calcite or dolomite, probably in the form of $\mathrm{Ca}_{2} \mathrm{UO}_{2}\left(\mathrm{CO}_{3}\right)_{3}$ (Liu et al., 2008). For waters with $\mathrm{pH}<8$, the uranium species are adsorbed onto precipitated iron oxides (e. g. Waite et al., 1994; Wazne et al., 2003). This is the reason why the adsorbents such as iron oxides are used as treatment methods for uranium removal from water (Katsoyiannis and Zouboulis, 2013). The slight decrease of uranium concentration towards downstream, with $\mathrm{U}$ concentration higher than $15 \mu \mathrm{g} / \mathrm{L}$, more than $1 \mathrm{~km}$ downstream of mine dumps and open pit lakes, is due to the high mobility of U (VI). The evaporation of waters leads to the formation of secondary uranium minerals, that can justify the decrease of $U$ concentration in surface waters in summer.

Principal Component Analysis is a non-parametric method of classification and it does not make assumptions on data's statistical distribution. Its main goal is looking for outliers and strong groupings in the plots and, therefore, specifying data patterns (Jolliffe, 2002). It was used the Spearman's correlation index to diminish the weight of frequent outliers (Candeias et al., 2011). All attributes and samples were considered active and contributed for the new components construction, except the open pit lake samples which were plotted in supplementary, as they constitute severe outliers, for all the elements. The first four components explain $74 \%$ of the total variability and so the ones retained for the subsequent evaluation.

Most of the metals, such as $\mathrm{Cd}, \mathrm{Sr}, \mathrm{Pb}, \mathrm{Ba}, \mathrm{B}, \mathrm{Ni}, \mathrm{Co}, \mathrm{Zn}$ and $\mathrm{Cu}$ constitute a group deeply connected to the natural geological characteristics of the surveyed settlement, mainly granite and associated mineralizations (Fig. 6). The metal concentrations in solution will depend on the water's physical conditions, the increasing due to dissolution from the solid precipitates.

Calcium, Mg, Na, $\mathrm{Cl}$ and EC define another group, suggesting that these major cations and anion are the principal contribution to the water's grade of mineralization, as well as the observed EC values. The open pit lake samples are close to this last group which could be explained by the higher observed water mineralization. Furthermore, the weathering of basic rock dykes and the probable addition of lime could have increased the local $\mathrm{pH}$ and contribute significantly to the final total water mineralization.

Uranium defines an independent group. The high grade of $\mathrm{U}$ observed in the surface water and groundwater may be related to the basic rocks dykes leaching, with uranium minerals dissolution depending on the water's physical-chemical conditions.

In general, the $\mathrm{U}$ concentrations of water from the abandoned 
Table 2

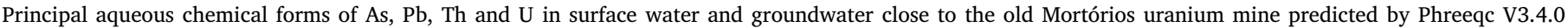
(Parkhurst and Appelo, 2013) and thermochimie database (Andra, 2009).

\begin{tabular}{|c|c|c|c|c|c|c|c|c|c|}
\hline Species names (\%) & $\begin{array}{l}\text { MOT-1 op } \\
\text { April } 2014\end{array}$ & $\begin{array}{l}\text { MOT-2 op } \\
\text { April } 2014\end{array}$ & $\begin{array}{l}\text { Mot-13 st April } \\
2014\end{array}$ & $\begin{array}{l}\text { Mot-15 st April } \\
2014\end{array}$ & $\begin{array}{l}\text { Mot-15 st Feb } \\
2015\end{array}$ & $\begin{array}{l}\text { Mot-9 w Feb } \\
2015\end{array}$ & $\begin{array}{l}\text { Mot-14 w Feb } \\
2015\end{array}$ & $\begin{array}{l}\text { Mot-19 w Feb } \\
2015\end{array}$ & $\begin{array}{l}\text { Mot-21 w April } \\
2014\end{array}$ \\
\hline $\mathrm{H}\left(\mathrm{AsO}_{4}\right)^{2-}$ & 46.66 & 70.89 & 3.37 & 13.04 & 92.45 & 28.28 & 74.23 & 11.56 & 0.97 \\
\hline $\mathrm{H}_{2}\left(\mathrm{AsO}_{4}\right)^{-}$ & - & - & 96.10 & 86.33 & 6.34 & 71.00 & 24.32 & 87.54 & 98.38 \\
\hline $\mathrm{HAsO}_{4}{ }^{2-}$ & 12.72 & - & - & - & - & - & - & - & - \\
\hline $\mathrm{Ca}\left(\mathrm{HAsO}_{4}\right)$ & 3.60 & 6.23 & - & - & 0.72 & - & 1.20 & - & - \\
\hline $\mathrm{Ca}\left(\mathrm{AsO}_{4}\right)^{-}$ & - & 22.00 & - & - & - & - & - & - & $\begin{array}{l}- \\
-\end{array}$ \\
\hline $\mathrm{Pb}^{2+}$ & - & - & 88.73 & 74.25 & & 75.65 & - & - & 96.77 \\
\hline $\mathrm{PbSO}_{4}$ & - & - & 4.46 & 3.51 & & 2.86 & - & - & 0.90 \\
\hline $\mathrm{PbOH}^{+}$ & 2.13 & 2.07 & - & - & & 1.53 & - & - & - \\
\hline $\mathrm{Pb}(\mathrm{OH})_{2}$ & 0.74 & - & - & - & & - & - & - & - \\
\hline $\mathrm{PbCO}_{3}$ & 80.18 & 91.25 & - & 7.23 & & 19.36 & - & - & 0.73 \\
\hline $\mathrm{Pb}(\mathrm{CO} 3)_{2}{ }^{2-}$ & 16.76 & 6.02 & - & - & & - & - & - & - \\
\hline $\mathrm{Pb}\left(\mathrm{B}(\mathrm{OH})_{4}\right)^{+}$ & - & - & 3.95 & 13.89 & & - & - & - & 0.97 \\
\hline $\operatorname{Th}(\mathrm{OH})_{3}\left(\mathrm{CO}_{3}\right)^{-}$ & 75.30 & 72.23 & - & 12.40 & 91.20 & 51.65 & 79.99 & 17.50 & - \\
\hline $\mathrm{Th}(\mathrm{OH})_{2}\left(\mathrm{CO}_{3}\right)_{2}{ }^{2-}$ & 20.64 & 24.20 & - & - & 2.88 & 2.29 & 3.10 & - & - \\
\hline $\mathrm{Th}(\mathrm{OH})_{2}\left(\mathrm{CO}_{3}\right)$ & - & - & 0.87 & 22.33 & 1.65 & 35.20 & 7.17 & 34.95 & 2.03 \\
\hline $\mathrm{Th}(\mathrm{OH})_{3}{ }^{+}$ & - & - & - & 6.56 & - & 6.85 & 1.99 & 12.45 & 1.14 \\
\hline $\operatorname{Th}(\mathrm{OH})_{2}^{2+}$ & - & - & - & 1.08 & - & - & - & 2.41 & 2.21 \\
\hline $\mathrm{Th}(\mathrm{OH})_{4}$ & 3.78 & 3.25 & - & 1.34 & 4.02 & 3.35 & 7.73 & 2.19 & - \\
\hline $\mathrm{Th}_{4}(\mathrm{OH})_{12}{ }^{4+}$ & - & & - & - & - & - & & 2.04 & - \\
\hline $\mathrm{ThF}_{3}{ }^{+}$ & - & - & 34.38 & 18.92 & - & - & - & 9.57 & 15.62 \\
\hline $\mathrm{ThF}^{3+}$ & - & - & - & - & - & - & - & - & 5.90 \\
\hline $\mathrm{ThF}_{2}{ }^{2+}$ & - & - & 26.44 & 12.49 & - & - & - & 11.69 & 69.70 \\
\hline $\mathrm{ThF}_{4}$ & - & - & 37.21 & 24.07 & - & - & - & 6.48 & 2.86 \\
\hline $\mathrm{UO}_{2}{ }^{2+}$ & - & - & 4.37 & 1.18 & - & - & & 2.05 & 13.09 \\
\hline $\mathrm{UO}_{2} \mathrm{CO}_{3}$ & - & - & 82.65 & 87.00 & 3.06 & 76.26 & 15.99 & 83.74 & 78.93 \\
\hline $\mathrm{UO}_{2}\left(\mathrm{CO}_{3}\right)_{2}^{2-}$ & - & - & 0.98 & 3.89 & 8.88 & 8.78 & 12.53 & 1.85 & - \\
\hline $\mathrm{UO}_{2}\left(\mathrm{CO}_{3}\right)_{3}^{4-}$ & 1.12 & - & - & - & 7.27 & - & 1.89 & - & \\
\hline $\mathrm{CaUO}_{2}\left(\mathrm{CO}_{3}\right)_{3}{ }^{2-}$ & 38.52 & 35.82 & - & - & 28.53 & - & 16.48 & - & \\
\hline $\mathrm{Ca}_{2} \mathrm{UO}_{2}\left(\mathrm{CO}_{3}\right)_{3}$ & 60.35 & 63.23 & - & - & 5.83 & 1.58 & 6.27 & - & \\
\hline$\left(\mathrm{UO}_{2}\right)_{2}\left(\mathrm{CO}_{3}\right)(\mathrm{OH})_{3}{ }^{-}$ & - & - & & 2.09 & 46.14 & 9.45 & 45.89 & 5.04 & \\
\hline $\mathrm{UO}_{2} \mathrm{OH}^{+}$ & - & - & 2.32 & 2.39 & - & 1.84 & - & 3.50 & 2.31 \\
\hline $\mathrm{UO}_{2} \mathrm{~F}^{+}$ & - & - & 7.67 & 2.42 & - & - & - & 2.28 & 3.93 \\
\hline $\mathrm{UO}_{2}\left(\mathrm{HAsO}_{4}\right)$ & - & - & 1.05 & - & - & - & - & 1.31 & 1.11 \\
\hline
\end{tabular}

Mot - Mortórios; op - open pit lake; st - stream; w - well; - not detected.

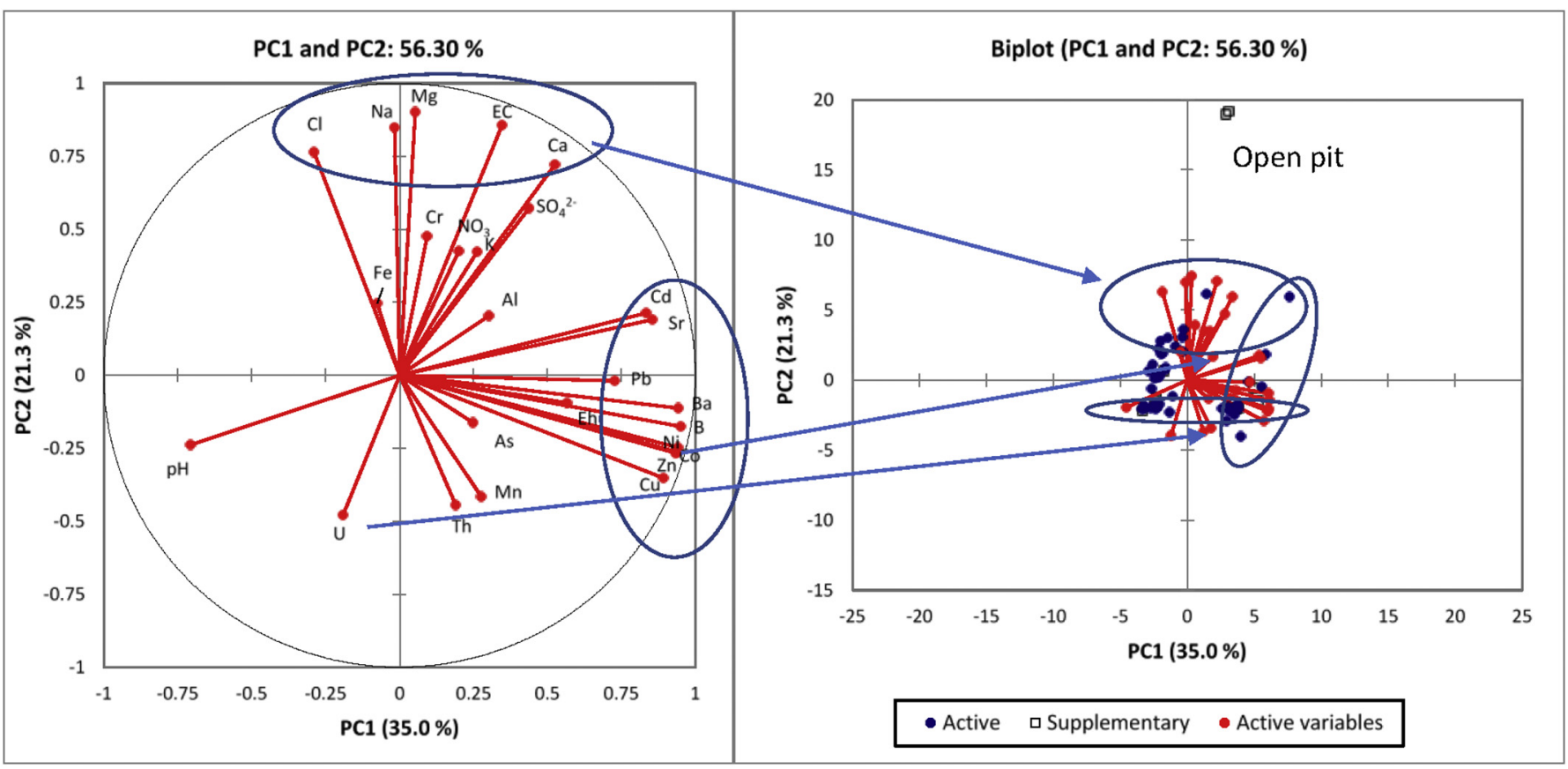

Fig. 6. Plot of PC1 and PC2 factors from waters of the abandoned Mortórios uranium mine area. 


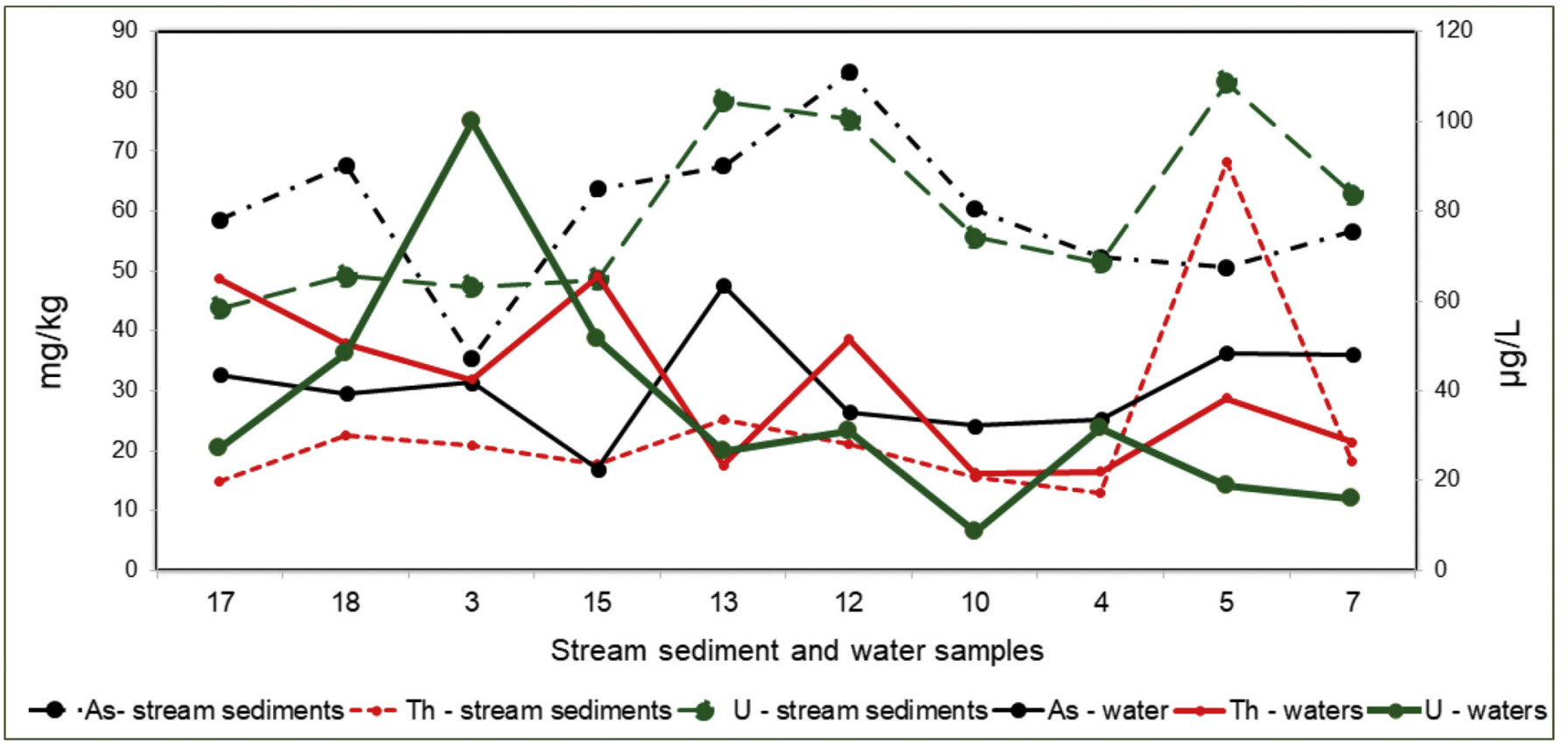

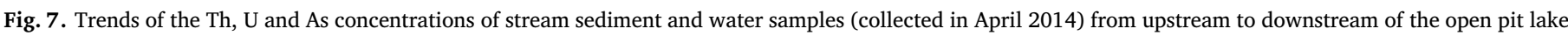
and dumps of the abandoned Mortórios uranium mine area.

Mortórios uranium mine area are higher than the $17 \mu \mathrm{g} / \mathrm{L}$ and $20 \mu \mathrm{g} / \mathrm{L}$ (Appendix A) for drinking water indicated by the Australian and Canadian guidelines, respectively (NHR, NRMMC, 2011; Health Canada, 2017). Most of the water samples have higher uranium concentrations than the $30 \mu \mathrm{g} / \mathrm{L}$ for drinking water indicated by the World Health Organization (WHO, 2017). Some surface water and groundwater are also contaminated in $\mathrm{Cd}, \mathrm{Cr}, \mathrm{Cu}, \mathrm{Fe}, \mathrm{Mn}, \mathrm{Ni}, \mathrm{Pb}$ and $\mathrm{As}$ and must not be used for human consumption (Portuguese Decrees, 1998, 2007, 2017). Some water samples have Cd concentrations higher than the $10 \mu \mathrm{g} / \mathrm{L}$ of $\mathrm{Cd}$ recommended for agricultural use in Portugal (Portugal Decree, 1998).

\subsection{Geochemistry of stream sediments}

The Th has a tendency to decrease to downstream, however has an abrupt increase on its concentration in the stream sediment 5 (Fig. 7), due to a streambed morphology in this portion of the stream that favours more finer sediment deposition that adsorbs the Th. The high Th and $U$ concentrations that occur $>1 \mathrm{~km}$ at downstream of the open pit lake and mine dumps (Fig. 7) reveal the high dispersion degree of contamination. Moreover, the high $\mathrm{W}$ concentration of stream sediment 5 (Table 1 ) is due to the contribution of the old W-Sn Fonte da Madre mine, which is located $3 \mathrm{~km}$ north of the abandoned Mortórios mine. Arsenic and $\mathrm{U}$ present high concentrations (about three times more) compared with the other metals, metalloid and Th (Fig. 7). Despite the Th concentration being lower than that of $\mathrm{U}$, the median Th concentration $(19.45 \mathrm{mg} / \mathrm{kg})$ is higher than the median Th concentration of European soils $(7.24 \mathrm{mg} / \mathrm{kg}$ ) (Salminen et al., 2005). At $>1 \mathrm{~km}$ downstream of the open pit lake and dumps, As $(56.6 \mathrm{mg} / \mathrm{kg})$, Th $(18.1 \mathrm{mg} / \mathrm{kg})$ and $\mathrm{U}(62.9 \mathrm{mg} / \mathrm{kg})$ in stream sediments are higher than their medians in stream sediments from Portugal (Ferreira, 2000), putting the Marialva's population at environmental risk due to the dispersion of these contaminants close to the village. This is mainly due to the mineralization in arsenopyrite of quartz veins that cut the porphyritic granite and the predominance of torbernite and autunite from basic rock dykes as the main ore minerals in the abandoned Mortórios mine area. The near neutral $\mathrm{pH}$ of stream sediments from Mortórios promotes the mobility of As (Neiva et al., 2016b; Carvalho et al., 2017; Antunes et al., 2018). Whereas the U, predominantly as hexavalent species, has high mobility and can be dispersed over long distances in the streams. The $U$ concentrations in waters towards downstream clearly decrease, while the $U$ concentration in stream sediments increase (Fig. 7). The $\mathrm{U}$ is adsorbed by the iron- and aluminium-oxyhydroxides present in the stream sediments, as happens in other reported contaminated areas by historical uranium mining (Zielinski et al., 2008). Kaolinite and smectite are also important clay minerals on the adsorption of U (Bachmaf and Merkel, 2011). The Fe and As concentrations of stream sediments from Mortórios present a positive correlation (Fig. 8), suggesting that As is adsorbed by Fe-oxyhydroxides (e.g. Neiva et al., 2016b). According to the Geo-accumulation (Igeo) index (Müller 1979, 1981 and 1986), taking into account the element background of stream sediments from Portugal (Ferreira, 2000), the stream sediments from Mortórios are moderately to heavily contaminated in As and Th and heavily to extremely contaminated in $\mathrm{U}$ and $\mathrm{W}$ (Table 3). The stream sediment 5 that is heavily contaminated in Th and heavily to extremely contaminated in $\mathrm{U}$ and $\mathrm{W}$.

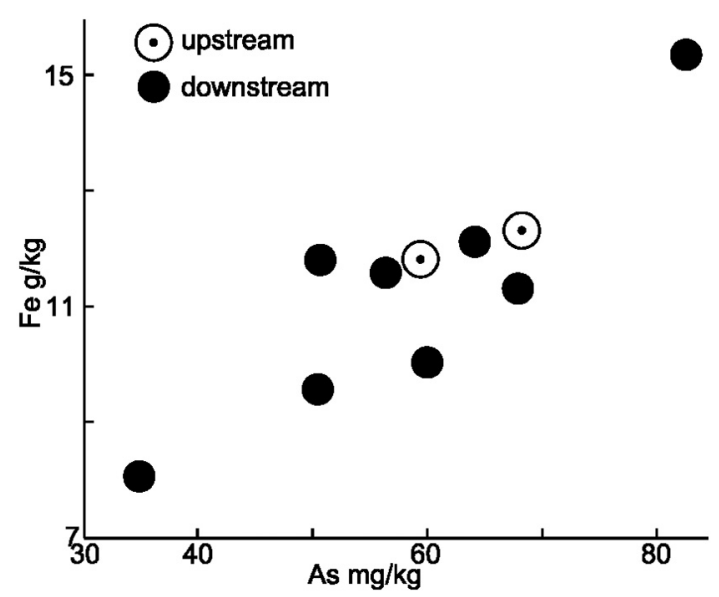

Fig. 8. Correlation between Fe and As of stream sediments from upstream and downstream of the open pit lake and dumps from the abandoned Mortórios uranium mine area. $\mathrm{r}=0.908, \mathrm{p}<0.01$. 
Table 3

Geo-accumulation (Igeo) index for metals and the metalloid As of stream sediments from the abandoned Mortórios uranium mine area.

\begin{tabular}{|c|c|c|c|c|c|c|c|c|}
\hline & \multicolumn{4}{|c|}{ Calculated-Igeo values } & \multicolumn{4}{|c|}{ Igeo-classes } \\
\hline & As & $\mathrm{Th}$ & $\mathrm{U}$ & $\mathrm{W}$ & As & Th & $\mathrm{U}$ & W \\
\hline \multicolumn{9}{|c|}{ Outside the mine influence area } \\
\hline SD17 & 2.1 & 1.3 & 3.5 & 5.5 & 3 & 2 & 4 & 6 \\
\hline SD18 & 2.3 & 1.9 & 3.7 & 6.1 & 3 & 2 & 4 & 6 \\
\hline \multicolumn{9}{|c|}{ Inside the mine influence area } \\
\hline SD3 & 1.4 & 1.8 & 3.7 & 0 & 2 & 2 & 4 & 0 \\
\hline SD15 & 2.2 & 1.6 & 3.7 & 4.6 & 3 & 2 & 4 & 5 \\
\hline SD13 & 2.3 & 2.1 & 4.4 & 5.6 & 3 & 3 & 5 & 6 \\
\hline SD12 & 2.6 & 1.8 & 4.3 & 4.8 & 3 & 2 & 5 & 5 \\
\hline SD10 & 2.2 & 1.4 & 3.9 & 3.4 & 3 & 2 & 4 & 4 \\
\hline SD4 & 2.0 & 1.1 & 3.8 & 3.4 & 2 & 2 & 4 & 4 \\
\hline SD5 & 1.9 & 3.5 & 4.4 & 8.2 & 2 & 4 & 5 & 6 \\
\hline SD7 & 2.1 & 1.6 & 4.1 & 4.0 & 3 & 2 & 5 & 3 \\
\hline \multicolumn{9}{|c|}{$\begin{array}{l}\text { Igeo values for } \mathrm{Al}, \mathrm{Fe}, \mathrm{Co}, \mathrm{Cr}, \mathrm{Cu}, \mathrm{Mn}, \mathrm{Ni}, \mathrm{Pb}, \mathrm{Sb}, \mathrm{Sr} \text { and } \mathrm{Zn} \text { contents are }<0 \text {. } \\
\text { The Igeo-class is } 0 \text { for them. }\end{array}$} \\
\hline \multicolumn{9}{|c|}{ Correspondence between Igeo values and Igeo classes according to Müller (1979, 1981 and 1986) } \\
\hline \multicolumn{3}{|l|}{ Igeo } & \multicolumn{2}{|l|}{ Igeo-classes } & \multicolumn{3}{|c|}{ Sediment quality } & \\
\hline$<0$ & \multicolumn{4}{|c|}{0} & \multicolumn{3}{|c|}{ Practically uncontaminated } & \\
\hline$>0-1$ & \multicolumn{4}{|c|}{1} & \multicolumn{4}{|c|}{ Uncontaminated to moderately contaminated } \\
\hline$>1-2$ & \multicolumn{4}{|c|}{2} & \multicolumn{3}{|c|}{ Moderately contaminated } & \\
\hline$>2-3$ & \multicolumn{4}{|c|}{3} & \multicolumn{3}{|c|}{ Moderately to heavily contaminated } & \\
\hline$>3-4$ & \multicolumn{4}{|c|}{4} & \multicolumn{3}{|c|}{ Heavily contaminated } & \\
\hline$>4-5$ & \multicolumn{4}{|c|}{5} & \multicolumn{3}{|c|}{ Heavily to extremely contaminated } & \\
\hline$>5$ & \multicolumn{4}{|c|}{6} & \multicolumn{3}{|c|}{ Extremely contaminated } & \\
\hline
\end{tabular}

5.3. Comparison of waters and stream sediments from three abandoned uranium mine areas exploited from open pits in central Portugal

The three abandoned uranium mine areas are located in the uranium-bearing Beiras area of central Portugal. Mortórios is located in the Guarda county (Fig. 1a), but the other two areas Vale de Abrutiga and Mondego Sul are close to the reservoir of the Aguieira dam in the Mondego river, Coimbra county (Fig. 1a). At Mortórios, weathered basic rock dykes contain torbernite and autunite. This mine produced about $27 \mathrm{t}$ of $\mathrm{U}_{3} \mathrm{O}_{8}$ from 1982 to 1988 (this work). Quartz veins from Vale de Abrutiga contain saleeite and meta-saleeite. The mine produced the highest amount of uranium oxide $\left(\mathrm{U}_{3} \mathrm{O}_{8}\right)$ ca. 90 t between 1982 and 1989 (Pinto et al., 2004). Quartz veins exploited at Mondego Sul contain autunite, torbernite, meta-uranocircite and meta-saleeite. The mine produced about $75 \mathrm{t}$ of $\mathrm{U}_{3} \mathrm{O}_{8}$ from 1987 to 1991 (Neiva et al., 2016a).

\subsubsection{Waters}

There was an open pit lake in each uranium mine area and the water came from rainfall, groundwater inflow and run off from adjacent lowgrade ore from dumps. The water samples were collected before remediation in the three areas, in Mortórios during April and October 2014 and February and July 2015 (this work); in Vale de Abrutiga during May 1998 and February, May, August and September 1999 (Pinto et al., 2004); in Mondego Sul during July and March 2008 and December 2009 (Neiva et al., 2016a). Water data from the three areas are compared in Table 4.

Among the open pit lakes, the water from Vale de Abrutiga has the lowest $\mathrm{pH}$ values (Table 4) due to oxidation of sulphides, mainly pyrite from quartz veins, which caused dissolution of metals responsible for the highest $\mathrm{EC}$ values. It also has the highest concentrations of $\mathrm{SO}_{4}{ }^{2-}$, $\mathrm{Cu}, \mathrm{Fe}, \mathrm{Mn}, \mathrm{Zn}$ and $\mathrm{U}$ due to the dissolution of sulphides and the highest $\mathrm{U}$ concentration derived from the dissolution of uranium minerals from quartz veins. The surface water from Vale de Abrutiga has the lowest $\mathrm{pH}$ and the highest $\mathrm{EC}$ values and $\mathrm{SO}_{4}{ }^{2-}, \mathrm{Fe}, \mathrm{Mn}, \mathrm{Zn}$ and $\mathrm{U}$ concentrations and the lowest Th concentration compared to surface water downstream the other open pit lakes and dumps in Mortórios and
Mondego Sul and the drainage from a dump in the latter area (Table 4). In general, groundwater from Vale de Abrutiga has higher EC values and $\mathrm{Fe}, \mathrm{Mn}, \mathrm{Zn}$ and $\mathrm{U}$ concentrations than groundwater downstream the open pit lake and dumps of Mortórios (Table 4) attributed to a higher abundance of sulphides, particularly pyrite and sphalerite associated with a higher uranium mineralization in the former area. At Vale de Abrutiga, surface water has lower $\mathrm{pH}$ values and higher EC values and $\mathrm{SO}_{4}{ }^{2-}, \mathrm{Fe}, \mathrm{Mn}, \mathrm{Zn}, \mathrm{Th}$ and $\mathrm{U}$ concentrations than groundwater (Table 4) due to a higher dissolution of sulphides at the surface. However, at Mortórios this distinction does not occur, probably because sulphides occur in small quartz veins and uranium minerals occur in basic rock dykes and are less abundant than those from quartz veins of Vale de Abrutiga.

The open pit lake from Mortórios has higher $\mathrm{pH}$ and $\mathrm{EC}$ values and As, Th and $\mathrm{U}$ concentrations and lower $\mathrm{Mn}, \mathrm{Ni}$ and $\mathrm{Zn}$ concentrations than the open pit lake from Mondego Sul (Table 4). The $\mathrm{pH}$ values suggest that at Mortórios there is a higher abundance of accumulated water in the open pit during the years, resulting from the weathering of basic rock dykes, but also a probable addition of lime $\mathrm{Ca}(\mathrm{OH})_{2}$ by the EDM may have occurred as the Ca median $(38.9 \mathrm{mg} / \mathrm{L})$ is much higher than that $(7.6 \mathrm{mg} / \mathrm{L})$ of the open pit lake of Mondego Sul. Furthermore, at the open pit lake of Mortorios there were higher abundances of dissolved arsenopyrite and uranium minerals and a lower dissolution of sphalerite than at the open pit lake from Mondego Sul, probably because water samples were collected seven years later than at Mondego Sul and sphalerite was less abundant in quartz veins from Mortórios. However, the exploited tonnes of $\mathrm{U}_{3} \mathrm{O}_{8}$ from basic rock dykes are lower at Mortórios than those exploited from quartz veins at Mondego Sul. There is not a clear distinction between surface waters downstream of the open pit lakes and dumps of Mortórios and Mondego Sul. However, the median of Eh value and median values of $\mathrm{Cu}, \mathrm{Fe}, \mathrm{Mn}, \mathrm{Pb}, \mathrm{As}$, Th and U concentrations are higher at Mortórios (Table 4) indicating that more sulphides from quartz veins and uranium minerals from basic rock dykes were more dissolved at Mortórios than those minerals from quartz veins at Mondego Sul.

The water from Vale de Abrutiga was the most contaminated before 
Table 4

Comparison of water data before remediation from three abandoned uranium mine areas exploited from open pits in central Portugal.

\begin{tabular}{|c|c|c|c|c|c|c|c|c|c|}
\hline & \multicolumn{9}{|c|}{ Mortórios } \\
\hline & \multicolumn{3}{|c|}{ open pit lake } & \multicolumn{3}{|c|}{ surfw downstr } & \multicolumn{3}{|c|}{ grdw downstr } \\
\hline & Min & Max & Median & Min & Max & Median & Min & Max & Median \\
\hline $\mathrm{pH}$ & 8.42 & 9.23 & 8.8 & 5.29 & 7.93 & 6.2 & 5.33 & 7.23 & 6.21 \\
\hline Eh (mV) & 252 & 429 & 337 & 125 & 461 & 296 & 204 & 457 & 326 \\
\hline $\mathrm{EC}(\mathrm{mS} / \mathrm{cm})$ & 263 & 415 & 330 & 32 & 72 & 44.5 & 32 & 99 & 63 \\
\hline $\mathrm{SO}_{4}{ }^{2-}(\mathrm{mg} / \mathrm{L})$ & 56.9 & 95.6 & 80.0 & 2.2 & 15.7 & 6.3 & 2.7 & 46.2 & 12.9 \\
\hline $\mathrm{Mg}(\mathrm{mg} / \mathrm{L})$ & 16.9 & 23.0 & 19.7 & 0.89 & 3.2 & 1.51 & 1.28 & 4.8 & 2.50 \\
\hline $\mathrm{Cd}(\mu \mathrm{g} / \mathrm{L})$ & * & 23.1 & 0.0 & * & 13.4 & 2.8 & * & 20.2 & 1.1 \\
\hline $\mathrm{Cr}(\mu \mathrm{g} / \mathrm{L})$ & * & 69.2 & 0.0 & * & 49.5 & 0.0 & * & 47.0 & 0.0 \\
\hline $\mathrm{Cu}(\mu \mathrm{g} / \mathrm{L})$ & * & 23.3 & 1.47 & * & 24.0 & 2.2 & * & 23.1 & 0.0 \\
\hline $\mathrm{Fe}(\mu \mathrm{g} / \mathrm{L})$ & 1.79 & 30.5 & 5.4 & 16.7 & 453 & 76.4 & 3.9 & 211 & 30.4 \\
\hline $\mathrm{Mn}(\mu \mathrm{g} / \mathrm{L})$ & * & 27.8 & 8.7 & 0.77 & 70.9 & 26.0 & * & 122 & 17.0 \\
\hline $\mathrm{Ni}(\mu \mathrm{g} / \mathrm{L})$ & * & 36.7 & 0.0 & * & 24.3 & 0.0 & * & 24.0 & 0.0 \\
\hline $\mathrm{Pb}(\mu \mathrm{g} / \mathrm{L})$ & * & 71.3 & 1.92 & * & 13.5 & 3.3 & * & 16.5 & 1.36 \\
\hline $\mathrm{Zn}(\mu \mathrm{g} / \mathrm{L})$ & * & 22.9 & 0.0 & * & 17.4 & 0.0 & * & 17.7 & 0.0 \\
\hline As $(\mu \mathrm{g} / \mathrm{L})$ & 39.8 & 56.0 & 47.5 & 21.8 & 63.4 & 41.0 & 6.0 & 66.7 & 40.1 \\
\hline Th $(\mu \mathrm{g} / \mathrm{L})$ & 17.1 & 53.3 & 28.1 & * & 65.5 & 33.5 & * & 69.2 & 8.4 \\
\hline $\mathrm{U}(\mu \mathrm{g} / \mathrm{L})$ & 1004 & 1268 & 1165 & * & 100.0 & 28.6 & * & 103 & 28.4 \\
\hline
\end{tabular}

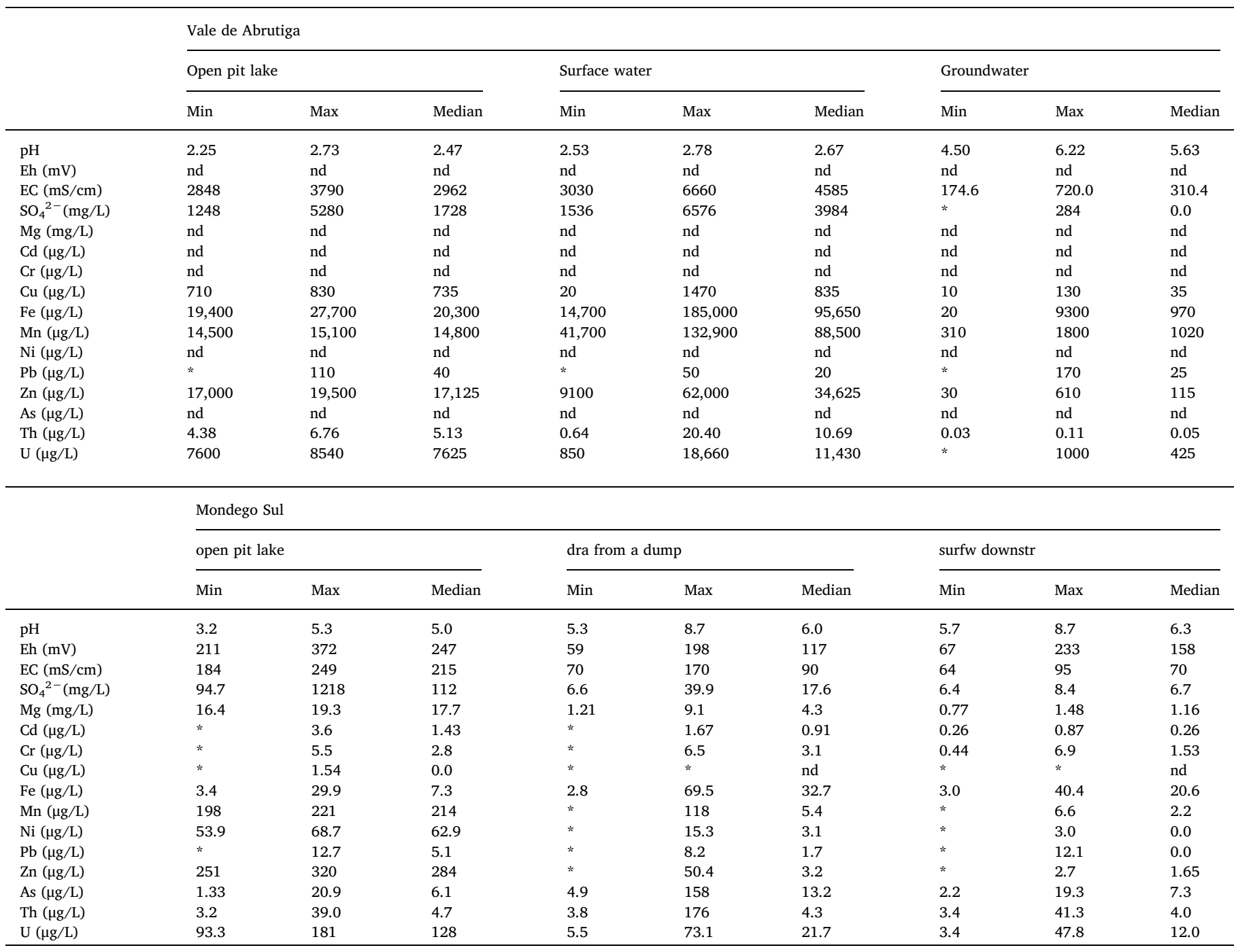

surfw downstr - surface water downstream of open pit lake and dumps; grdw downstr - groundwater downstream of open pit lake and dumps; dra - drainage; Min minimum; Max - maximum. * - below the limit of detection; nd - not determined. 
Table 5

Basic statistical parameters of element contents (ppm) of stream sediments downstream of the open pit lakes and dumps from the abandoned uranium mine areas of Mortórios, Mondego Sul and Vale de Abrutiga.

\begin{tabular}{|c|c|c|c|c|c|c|c|c|c|}
\hline & \multicolumn{3}{|c|}{ Mortórios } & \multicolumn{3}{|c|}{ Mondego Sul } & \multicolumn{3}{|c|}{ Vale de Abrutiga } \\
\hline & Min & Max & Median & Min & Max & Median & Min & Max & Median \\
\hline $\mathrm{U}$ & 47.4 & 81.5 & 53.5 & 67.1 & 266 & 85.0 & 27.8 & 301 & 58.0 \\
\hline Th & 13.0 & 68.2 & 19.5 & 115 & 281 & 180 & 3.3 & 10.8 & 9.6 \\
\hline As & 35.4 & 83.2 & 59.4 & 49.0 & 211 & 118 & nd & nd & nd \\
\hline $\mathrm{Pb}$ & 9.3 & 14.3 & 11.6 & 25.1 & 159 & 55.7 & 25.0 & 44.0 & 38.0 \\
\hline $\mathrm{Fe}(\%)$ & 0.8 & 1.53 & 1.2 & 1.2 & 3.8 & 3.0 & 2.7 & 23.9 & 3.8 \\
\hline Co & $*$ & 5.1 & 3.1 & 8.7 & 47.4 & 12.6 & 11.0 & 74.0 & 16.0 \\
\hline $\mathrm{Cr}$ & 4.6 & 15.7 & 12.9 & 14.2 & 66.1 & 37.2 & 70.0 & 107 & 99.0 \\
\hline $\mathrm{Cu}$ & $*$ & 8.9 & 7.7 & 18.3 & 47.4 & 29.7 & 18.1 & 66.5 & 41.7 \\
\hline $\mathrm{Zn}$ & 44.8 & 54.6 & 49.9 & 78.2 & 346 & 126 & 130 & 803 & 158 \\
\hline
\end{tabular}

Min - minimum; Max - maximum; *- below the detection limit; nd - not determined.

remediation. It might not have been used as drinking water due to the $\mathrm{U}$ concentration (WHO, 2017) and the other metals concentrations and might not also have been used for agriculture (Portuguese Decrees, $1998,2007,2017)$. This area was remediated from January 2007 to the beginning of June 2008 (EDM, 2017).

The $\mathrm{U}$ contamination of water is higher at Mortórios than at Mondego Sul. They must not be used as drinking water (WHO, 2017). Water from Mortórios is also more contaminated in $\mathrm{Mn}, \mathrm{Ni}$ and As than water from Mondego Sul and it also has contamination in $\mathrm{Cd}, \mathrm{Cr}, \mathrm{Fe}$ and $\mathrm{Pb}$ supporting that it must not be used for human consumption (Portuguese Decrees, 1998, 2007, 2017). Water samples from Mortórios have some significant $\mathrm{Cd}$ concentrations showing that the water must not also be used for agriculture (Portuguese Decree, 1998). Water from Mortórios has arsenic as As (V), whereas water from Mondego Sul has significant concentrations of As (III), which is the most toxic form of arsenic (Hughes et al., 2011).

\subsubsection{Stream sediments}

The stream sediments in the influence of the open pit lake and mine dumps from Mortórios have the lowest U median $(53.5 \mathrm{mg} / \mathrm{kg}$ ) when compared with those from Mondego Sul and Vale de Abrutiga (Table 5). Moreover, the median values of $\mathrm{Pb}, \mathrm{Co}, \mathrm{Cr}, \mathrm{Cu}$ and $\mathrm{Zn}$ concentrations are lower than the median values of those elements in stream sediments from Mondego Sul and Vale de Abrutiga. However, the Th median $(19.5 \mathrm{mg} / \mathrm{kg})$ of stream sediments from Mortórios is higher than the Th median of the stream sediments from Vale de Abrutiga $(9.6 \mathrm{mg} / \mathrm{kg}$ ). The contamination in the Mortórios area is mainly due to the dispersion of metals, metalloids and radionuclides in solution compared with other old uranium mining areas, that can also be affected by the transport of material from mine dumps to the streams. The As and $U$ are the elements with more potential to contaminate the environment downstream of the open pit lakes and mine dumps. The near neutral to alkaline $\mathrm{pH}$ of waters and near neutral $\mathrm{pH}$ of stream sediments at Mortórios reduce the As adsorption by the stream sediments (Jeppu and Clement, 2012) and the predominance of hexavalent form of $U$ favours its mobility in surface waters. Therefore, the stream sediments have an important role in the retention of $U$ and As through its sorption capacity and the decrease in the $\mathrm{U}$ and As contamination of waters towards downstream. Stream sediments from Mondego Sul have higher U, Th, $\mathrm{Pb}$ and lower $\mathrm{Co}, \mathrm{Cr}, \mathrm{Cu}$ and $\mathrm{Zn}$ median values than stream sediments from Vale de Abrutiga.

\section{Conclusions}

At Mortórios, there are small quartz veins containing sulphides and basic rock dykes up to $14 \mathrm{~m}$ thick with torbernite and autunite and cutting a porphyritic granite. Stream water and groundwater are slightly acidic to alkaline of pH 5.29-7.93 and 4.59-7.23, respectively. The high pH 8.43-9.23 values of the open pit lake and the median Ca concentration of $38.9 \mathrm{mg} / \mathrm{L}$ are due to weathering of basic rock dykes and suggest a probable addition of lime $\mathrm{Ca}(\mathrm{OH})_{2}$ by the EDM. The open pit lake has also the highest $\mathrm{EC}$ and TDS values and $\mathrm{F}^{-}, \mathrm{SO}_{4}{ }^{2-}, \mathrm{HCO}_{3}{ }^{-}$, $\mathrm{Na}, \mathrm{K}, \mathrm{Ca}, \mathrm{Mg}, \mathrm{Li}$ and $\mathrm{U}$ concentrations being a communication point that allows the leaching to the downstream of surface water and groundwater. Downstream of the open pit lake and dumps, the groundwater has higher, $\mathrm{F}^{-}, \mathrm{SO}_{4}{ }^{2-}, \mathrm{NO}_{3}{ }^{-}, \mathrm{PO}_{4}{ }^{3-}, \mathrm{HCO}_{3}{ }^{-}, \mathrm{K}, \mathrm{Ca}, \mathrm{Mg}$, $\mathrm{Al}, \mathrm{B}, \mathrm{Ca}, \mathrm{Cd}, \mathrm{Mn}, \mathrm{Sr}, \mathrm{Zn}, \mathrm{As}$, Th and $\mathrm{U}$ concentrations than the surface water due to leaching of basic rock dykes, quartz veins and granite. The highest U concentration occurred in the open pit lake in April 2014 due to the dissolution of uranium minerals after an intense raining winter (IPMA, 2018). A later less dilution was caused by a very warm and dry spring. However, in the stream water and groundwater downstream of the open pit lake the highest $U$ concentration occurred in February 2015, when the runoff and leaching from all rock types were the highest.

The principal component analysis (PCA) indicate a group consisting of $\mathrm{Cd}, \mathrm{Sr}, \mathrm{Pb}, \mathrm{Ba}, \mathrm{B}, \mathrm{Ni}, \mathrm{Co}, \mathrm{Zn}$ and $\mathrm{Cu}$ connected to granite and associated mineralization. Another group is defined by $\mathrm{Ca}, \mathrm{Mg}, \mathrm{Na}, \mathrm{Cl}$ and EC suggesting that they gave the main contribution to the water's grade mineralization. The U defines and independent group mainly related to the basic rock dykes.

In general, uranyl carbonate species dominate, but calcium uranyl carbonate complexes dominate mainly in the open pit lake. The Th occurs as carbonate hydroxide species. Arsenic occurs as As (V) in all waters and is as $\mathrm{Ca}\left(\mathrm{HAsO}_{4}\right)$ and $\mathrm{CaAs}\left(\mathrm{O}_{4}\right)^{-}$complexes in the open pit lake. In all the other waters, some As will be retained in ferrihydrite, goethite, hematite, maghemite and lepidocrocite. The water is contaminated in $\mathrm{U}, \mathrm{Cd}, \mathrm{Cr}, \mathrm{Cu}, \mathrm{Fe}, \mathrm{Mn}, \mathrm{Ni}, \mathrm{Pb}$ and $\mathrm{As}$ and must not be used for human consumption. Due to its contamination in Cd it must not also be used for agriculture. The alkaline $\mathrm{pH}$ values of the open pit lake favor the dispersion of As for surrounding waters and stream sediments and the high Ca concentrations favor the uranium mobility as calcium uranyl carbonate complexes. The stream sediments are contaminated in As, Th, U and W. At more than $1 \mathrm{~km}$ downstream of the open pit lake and dumps As, Th and $\mathrm{U}$ concentrations in water and stream sediments and $\mathrm{W}$ in stream sediments may cause environmental risk to the Marialva village.

The characteristics of three exploited uranium mine areas from open pits located in central Portugal, before remediation, were compared. In all of them sulphides occur in quartz veins. In two of them $U$ minerals also occur in these veins, but at Mortórios they occur in basic rock dykes. The Vale de Abrutiga area, that produced more $\mathrm{U}_{3} \mathrm{O}_{8}$ tonnes and water samples were collected 10 years after the mine was closed, shows the highest contamination. The Mondego Sul mine that produced lower $\mathrm{U}_{3} \mathrm{O}_{8}$ tonnes and water samples were collected 18 years after the mine was closed presents a lower contamination of water than at the Mortórios area which produced the lowest $\mathrm{U}_{3} \mathrm{O}_{8}$ tonnes and from which water samples were collected 27 years after the mine was closed. However, arsenic occurs as As (V) at Mortórios and as As (III) at the Mondego Sul area. The stream sediments from Mortórios have the lowest median values of $\mathrm{U}, \mathrm{Pb}, \mathrm{Co}, \mathrm{Cr}, \mathrm{Cu}$ and $\mathrm{Zn}$. Stream sediments from Vale de Abrutiga have higher $\mathrm{Co}, \mathrm{Cr}, \mathrm{Cu}$ and $\mathrm{Zn}$ and lower $\mathrm{U}$, Th and $\mathrm{Pb}$ median values than stream sediments from Mondego Sul.

We hope that EDM, S.A. (Mining Development Enterprise), which is responsible for the remediations of Portuguese abandoned mine areas, will use the data and information provided in this study to plan the necessary remediation.

Supplementary data to this article can be found online at https:// doi.org/10.1016/j.gexplo.2019.03.020.

\section{Acknowledgments}

We are grateful to J.F.C. Mendes for the determination of organic 
matter and cation exchange capacity in samples of stream sediments. We thank Robert Ayuso and three anonymous reviewers for their comments. Some financial support was given by the project UID/GEO/ 04035/2013.

\section{References}

ANDRA, 2009. ThermoChimie Version 7b, C.RP.ASTR.04.0032.

Antunes, I.M.H.R., Neiva, A.M.R., Albuquerque, M.T.D., Carvalho, P.C.S., Santos, A.C.T., Cunha, P.P., 2018. Potential toxic elements in stream sediments, soils and waters in an abandoned radium mine (central Portugal). Environ. Geochem. Health 40, 521-542.

Araújo, P.V., Clamote, F., Carapeto, A., Almeida, J.D., Porto, M., Pereira, E.P., Lourenço, J., Malveiro, S., et al., 2018. Flora-On: Flora de Portugal Interactiva. Sociedade Portuguesa de Botânica. http://www.flora.on.pt/\#w\%C3\%A1rvore\%2C+m\%C3\% AAda.

AREVA, 2004. Bilan Décennal Environmental 1994-2003. Établissement de Bessines.

Azevedo, M., Aguado, B., 2013. Origem e instalação de Granitóides Variscos na Zona Centro-Ibérica. In: Dias, R., Araújo, A., Terrinha, P., Kullberg, J. (Eds.), Geologia de Portugal. vol. I. Escolar Editora, pp. 377-401.

Bachmaf, S., Merkel, B.J., 2011. Sorption of uranium (VI) at the clay mineral-water interface. Environ. Earth Sci. 63, 925-934.

Barnett, M.O., Jardine, P.M., Brooks, S.C., Selim, H.M., 2000. Adsorption and transport of uranium (VI) in surface media. Soil Sci. Am. J. 64, 908-917.

British standard (BS) 7755, 1995a. Soil Quality, Part 3. Chemical Methods, Section 3.2. Determination of pH. vol. 10390. ISO, pp. 1995.

British standard (BS) 7755, 1995b. Soil Quality, Part 3. Chemical Methods, Section 3.4. Determination of Specific Electrical Conductivity. vol. 11265. ISO, pp. 1994.

Brown, E., Skougstad, W., Fishman, M.J., 1970. Method for collection and analysis of water samples for dissolved minerals and gases. In: Techniques of Water-Resources Investigations of the United States Geologial Survey. Chap. A1, Book 5, Laboratory Analysis, 40-44. United States Department of the Interior.

Candeias, C., da Silva, E.F., Salgueiro, A.R., Pereira, H.G., Reis, A.P., Patinha, C., Matos, J.X., Ávila, P.H., 2011. The use of multivariate statistical analysis of geochemecial data for assessing the spatial distribution of soil contamination by potentially toxic elements in the Aljustrel mining area (Iberian Pyrite Belt, Portugal). Environ. Earth Sci. $62,1461-1479$.

Carvalho, F.P., 2014. The national radioactivity monitoring program for the regions of uranium mines and uranium legacy sites in Portugal. Proc. Earth Plan. Sc. 8, 33-37.

Carvalho, F.P., 2015. O urânio em Portugal. Que risco apresenta. Revista Segurança 224, 12-15. https://revistaseguranca.eu/pt/o-uranio-em-portugal.

Carvalho, F.P., Malta, M., Oliveira, J.M., 2010. III. Programa específico para as regiões das minas de urânio. Relatório UPSR-A, n ${ }^{\circ}$ 3710. Instituto Tecnológico e Nuclear, Unidade de Protecção e Segurança Radiológica, pp. 101-146.

Carvalho, P.C.S., Neiva, A.M.R., Silva, M.M.V.G., Santos, A.C.T., 2017. Human health risks in and old gold mining area with circum-neutral drainage, Central Portugal. Environ. Geochem. Health 39, 43-62.

Custódio, E., Llamas, M.R., 2001. Hidrologia subterrânea, $2^{\mathrm{a}}$ edição. vol. tomo I Ediciones Omega, Barcelona.

Dias da Silva, Í., Jensen, S., Gonzáles-Clavijo, E., 2014. Trace fossils from the Desejosa Formation (Schist and Greywacke complex, Douro Group, NE Portugal): new Cambrian age constraints. Geol. Acta 12, 109-120.

Duff, M.C., Amrhein, C., 1996. Uranium (VI) adsorption on goethite and soil in carbonate solutions. Sol., Sci. Soc. Am. J. 60, 1393-1397.

EDM, 2017. Estudos, projetos e obras. http://edm.pt/area-ambiental/estudos-projetos e obras.

Farias, P., Gallastegui, G., Lodeiro, F.G., Marquinez, J., Parra, L.L.M., Catalán, J.R.M., Macia, G.P., Fernandez, L.R., 1987. Appontaciones al conocimiento de la lito-estratigrafia y estrutura de Galicia Central. IX Reunion de Geologia do Oeste Peninsular. In: Publ. Mus. Mineral., Geol. Fac. Ciências, Univ. Porto, Program Abstr.1, pp. 411-431.

Ferreira, A., 2000. Dados geoquímicos de base de sedimentos fluviais de amostragem de baixa densidade de Portugal continental: estudo de factores de variação regional. PhD Thesis. Univ. Aveiro, Portugal.

Ferreira, N., Iglesias Ponce de Léon, M., Noronha, F., Ribeiro, A., Ribeiro, M.L., 1987. Granitóides da Zona Centro Ibérica e seu enquadramento geodinâmico. In: Bea, F., Carnicero, A., Gonzalo, J.C., López Plaza, M., Rodriguez Alonso, M.D (Eds.), Geologia de los Granitoides e Rocas Asociadas del Macizo Hespérico. Editorial Rueda, Madrid, pp. 37-51.

Fortes, C., Filipe, A., Parra, A., 2001. SIORMIMP: 1510U. Mortórios (4 pp),

Fox, P.M., Davis, J.A., Zachara, J.M., 2006. The effect of calcium on aqueous uranium (VI) speciation and adsorption to ferrihydrite and quartz. Geoch. Cosm. Acta 70, 1379-1387.

Gómez, P., Garralón, A., Buil, B., Turrero, M.J., Sánchez, L., De la Cruz, B., 2006. Modeling of geochemical processes related to uranium mobilization in groundwater of a uranium mine. Sci. Total Environ. 366, 295-309.

Grenthe, I., Fuger, J., Konings, J.M., Lomire, J., Muller, B., Nguyen-Trung, C., Wanner, H., 2003. Chemical thermodynamics of uranium. In: Wanner, H., Forest, I. (Eds.), Nuclear Agency Organization for Economic Co-Operation and Development, (735 pp., France).

GSJ, 2005. Atlas of Eh-pH diagrams. Intercomparison of thermodynamic databases. Geol. Surv. Japan, Open File Rep 419, 29-30.

Health Canada, 2017. Guidelines for Canadian Drinking Water Quality-Summary Table Water and Air Quality Bureau, Healthy Environments and Consummer Safety Branch.
Health Canada, Ottawa, Ontario.

Hughes, M.F., Beck, B.D., Chen, Y., Lewis, A.S., Thomas, D.J., 2011. Arsenic exposure and toxicology: a historical perspective. Toxicol. Sci. 13, 305-332.

IGE (Instituto Geográficos do Exército), 1994. Carta militar de Portugal, escala 1:25 000, continente, série M888, Folha 160, Torre do Terranho (Trancoso), $2^{\mathrm{a}}$ edição. .

IPMA (Instituto Português do Mar e da Atmosfera), 2014. Boletim Climatológico Janeiro a Dezembro de 2014 para Portugal Continental. http://www.ipma.pt/pt/publicacoes/. IPMA (Instituto Português do Mar e da Atmosfera), 2015. Boletim Climatológico Janeiro a Dezembro de 2015 para Portugal Continental. http://www.ipma.pt/pt/publicacoes/.

IPMA (Instituto Português do Mar e da Atmosfera), 2018. Clima de Portugal Continental. https://www.ipma.pt/pt/oclima/normais.clima/.

Jambor, J.L., 1994. Mineralogy of sulfide-rich tailings and their oxidation products. Environmental geochemistry of sulfide mine-wastes. Mineral. Assoc. Canada Short Course 22 (59-102 pp).

JEN (Junta de Energia Nuclear), 1959. Relatório de execução do plano de sanjas n 247 (Mortórios). Informação n 135/49.

Jeppu, G.P., Clement, P.T., 2012. A modified Langmuir-Freundlich isotherm model for simulating pH-dependent adsorption effects. J. Contaminant Hyd. 129-130, 46-53.

Jolliffe, I.T., 2002. Principal Component Analysis. In: Library of Congress Cataloging - in Publication Data, Second edition. Springer-Verlag, New York.

Kanzari, A., Gérard, M., Boekhout, F., Galoisy, L., Calas, G., Descostes, M., 2017. Impact of incipient weathering on uranium migration in granitic waste rock piles from former U mines (Limousin, France). J. Geochim. Expl. 183, 114-126.

Katsoyiannis, I.A., Zouboulis, A.I., 2013. Removal of uranium from contaminated drinking water: a mini review of available treatment methods. Desalin. Water Treat. 51 (13-15), 2915-2925.

Kim, S.S., Baik, M.H., Choi, J.W., Shin, H.S., Yun, J.I., 2010. The dissolution of $\mathrm{ThO}_{2}(\mathrm{cr})$ in carbonate solutions and a granitic groundwater. Rad. Nucl. Chem. 286, 91-97.

Langmuir, D., 1978. Uranium solution-mineral equilibria at low temperatures with applications to sedimentary ore deposits. Geochim. Cosmochim. Acta 42, 547-570.

Langmuir, D., Herman, J.S., 1980. The mobility of thorium in natural waters at low temperatures. Geochim. Cosmoch. Acta 44, 1753-1766.

Liu, C., Zachara, J., Qafoku, N.P., Wang, Z., 2008. Scale-dependent desorption of uranium from contaminated subsurface sediments. Water Resour. Res. 44, W08413.

Lottermoser, B.G., 2010. Mine Wastes: Characterization, Treatment and Environmental Impacts. Springer, Berlin, Germany.

Madruga, M.J., Carvalho, F., Reis, M., Alves, J., Corisco, J., Trindade, R., Lopes, I., Abrantes, J., Silva, L., Torres, L., Portugal, L., Malta, M., Libânio, A., Mourato, A., Silva, G., Oliveira, J.M., Santos, L., Batista, A., Gomes, A.R., Carvalhal, G., Fonseca, H., Melo, J., Pereira, M., 2010. Programas de Monitorização Radiológica Ambiental (Ano 2009) Relatório UPSR-A, n³7/10. Instituto Tecnológico e Nuclear, Unidade de Protecção e Segurança Radiológica (146pp.).

Mathew, B.P., Samant, H.P., 2014. Spatio-Temporal characteristics of groundwater quality and GIS based Quality maping around Nandurbarcity, Nandurbar District, Maharashtra, India. In: Proceedings of the 4th International Conference on Hydrology and Watershed Management. 29th October to 1st November 2014. Center for water resources, Telangana State, India.

Milvy, P., Cothern, R., 1990. Scientific background for the development of regulations for radionuclides in drinking water. In: Cothern, R., Rebers, P. (Eds.), Radon, Radium and Uranium in Drinking Water, pp. 1-16.

Müller, G., 1979. Schwermetalle in den sedimenten der Rheins-Veränderungen seit, 1971. Die Umschau in Wissenschaft und Technik 79, 778-783.

Müller, G., 1981. Die schwermetallbelastung der sedimente des neckars und seiner Nebenflusse: Eine Bestandsaufnahme. Chemiker Zeitung 6, 157-164.

Müller, G., 1986. Schadstoffe in sedimenten-sedimenteals Schadstoffe. Mitt. Österr. Geol. Ges. 79, 107-126.

Neiva, A.M.R., Carvalho, P.C.S., Antunes, I.M.H.R., Silva, M.M.V.G., Santos, A.C.T., Cabral Pinto, M.M.S., Cunha, P.P., 2014. Contaminated water, stream sediments and soils close to the abandoned Pinhal do Souto uranium mine, Central Portugal. J. Geochem. Explor. 136, 102-117.

Neiva, A.M.R., Carvalho, P.C.S., Antunes, I.M.H.R., Santos, A.C.T., Cabral-Pinto, M.M.S., 2015. Spatial and temporal variability of surface water and groundwater before and after the remediation of a Portuguese uranium mine area. Chem. Erde 75, 345-356.

Neiva, A.M.R., Antunes, I.M.H.R., Carvalho, P.C.S., Santos, A.C.T., 2016a. Uranium and arsenic contamination in the former Mondego Sul uranium mine area, Central Portugal. J. Geom. Explor. 162, 1-15.

Neiva, A.M.R., Carvalho, P.C.S., Antunes, I.M.H.R., Cabral Pinto, M.M.S.C., Santos, A.C.T., Cunha, P.P., Costa, M.M., 2016b. Spatial variability of soils and stream sediments and the remediation effects in a Portuguese uranium mine area. Chem. Erde 76, 501-518.

Nelson, D.W., Sommers, L.E., et al., 1996. Total carbon, organic carbon and organic matter. In: Page, A.L. (Ed.), Methods of Soil Analysis, Part 2, $2^{\text {nd }}$ ed. Agronomy. vol. 9 Am. Soc. Agron., Inc., Madison, W1 (961-1010 pp).

NHMRC, NRMMC, 2011. Australian Drinking Water Guidelines, Paper 6 National Water Quality Management Strategy. National Health and Medical Research Council, National Resource Management Ministerial Council, Commonwealth of Australia, Canberra.

Nordstrom, D.K., Wilde, F.D., 2005. Reduction oxidation potential (electrode method). In: Wilde, F.D. (Ed.), Field Measurements: U.S. Geological Survey Techniques of Water Resources Investigations, book, chap. A6, version 1.2 (9/2005). https://water.usgs. gov/owq/FieldManualy/Chapter6/6.5_V_1.2.pdf.

Oliveira, J., Pereira, E., Piçarra, J., Young, T., Romano, M., 1992a. O Paleozóico Inferior de Portugal: síntese da estratigrafia e da evolução paleogeográfica. In: Gutiérrez Marco, J.C., Saavedra, J., Rábano, I. (Eds.), Paleozóico Inferior de Ibero-América. Univ. Extremadura, Badajoz (359-375 pp.).

Oliveira, J.T., Pereira, E., Ramalho, M., Antunes, M.T., Monteiro, J.H., 1992b. Carta 
Geológica de Portugal à escala 1:500 000, Folha Norte, $5^{a}$ edição. Serv. Geol. Portugal, Lisboa.

Oughton, D.H., Stromman, G., Salbu, B., 2013. Ecological risk assessment of central Asian mining sites: application of the ERICA assessment tool. J. Environ. Radioact. 123, 90-98.

Panagiotaras, D., Nikolopoulos, D., 2015. Arsenic occurrence and fate in the environment: a geochemical perspective. J. Earth Sci. Clim. Change 6, 1-9.

Parkhurst, D.L., Appelo, C.A.J., 2013. Description of input and examples for PHREEQC version 3-A computer program for speciation, batch-reaction, one-dimensional transport, and inverse geochemical calculations. In: U. S. Geological Survey Techniques and Methods, Book 6, (chap. A43).

Pereira, M.F., Linnemann, U., Hofmann, M., Chichorro, M., Solá, A.R., Medina, J., Silva, J.B., 2012. The provenance of late Ediacaran and early Ordovician siliciclastic rocks in the Southwest Central Iberian Zone: Constraints from detrital zircon data on northern Gondwana margin evolution during the late Neoproterozoic. Precambrian Res. 192-195, 166-189.

Pinto, M.M.S.C., Silva, M.M.V.G., Neiva, A.M.R., 2004. Pollution of water and stream sediments associated with the Vale de Abrutiga uranium mine, Central Portugal. Mine Water Environ. 23, 66-75.

Portuguese Decree, 1998. Decree 236/1998. Portuguese Legislation on Water Quality. Diário da República I-A. (3676-3722 pp).

Portuguese Decree, 2007. Portuguese Legislation on Water Quality. Diário da República IA (5747-5765 pp).

Portuguese Decree, 2017. Portuguese Legislation on Water Quality. Diário da República IA, Lisbon, $\mathrm{N}^{\circ} 235$. (6555-6576 pp).

Quintela, A., 2015. Remediação ambiental da antiga área mineira de Mortórios. Seminário de gestão, projeto, construção e encerramento de instalações de resíduos mineiros. Ordem dos Engenheiros, Lisboahttp://www.ordemengenheiros.pt/.

Salminen, R. (Chief-Ed.), Batista, M.J., Bidovec, M., Demetriades, A., De Vivo, B., De Vos, W., Duris, M., Gilucis, A., Gregorauskiene, V., Halamic, J., Heitzmann, P., Lima, A., Jordan, G., Klaver, G., Klein, P., Lis, J., Locutura, J., Marsina, K., Mazreku, A.,
O'Connor, P.J., Olsson, S.A., Ottesen, R.-T., Petersell, V., Plant, J.A., Reeder, S., Salpeteur, I., Sandström, H., Siewers, U., Steenfelt, A., Tarvainen, T., 2005.

Geochemical Atlas of Europe. Part 1 - Background Information, Methodology and Maps. Geol. Surv. Finland, Espoo, Finland.

Selvakumar, R., Ramadoss, G., Menon, M.P., Rajendran, K., Thavamani, P., Naidu, R., Megharaj, M., 2018. Challenges and complexities in remediation of uranium contaminated soils: a review. J. Environ. Rad.

Thomas, G.W., 1982. Exchangeable cations. In: Page, A.L. (Ed.), Methods of Soil Analysis, Part 2, Second edition. Agronomy, Madison, W1 (9 p).

Tutu, H., Cukrowska, E.M., McCarthy, T.S., Hart, R., Chimuke, L., 2009. Radioactive disequilibrium and geochemical modeling as evidence of uranium leaching from gold tailing dumps in the Witwatersrand basin. Int. J. Environ. Anal. Chem. 89, 687-703.

Vercouter, T., Reiller, P.E., Ansoborlo, E., Février, L., Gilbin, R., Lomenech, C., Philippini, V., 2015. A modelling exercise on the importance of ternary alkaline earth carbonate species of uranium (VI) in the inorganic speciation of natural waters. Appl. Geochem. 55, 192-198.

Waite, T.D., Davis, J.A., Payne, T.E., Waychunas, G.A., 1994. Uranium N. X. (VI) adsorption to ferrihydrite: application of a surface complexation model. Geochim. Cosmochim. Acta 58, 5465-5478.

Wazne, M., Korfiatis, G.P., Meng, X., 2003. Carbonate effects on hexavalent uranium adsorption by iron oxyhydroxides. Environ. Sci. Technol. 37, 3619-3624.

WHO, 2017. Guidelines for Drinking- Water Quality: Fourth Edition Incorporating the First Addendum. 2017 World Health Organization, Geneva License: CC BY-NC-SA 3.0 IGO. Available at. http:/whqlibdoc.who.int/publications/2017/978924154851 eng.pdf.

Zammit, C.M., Brugger, J., Southam, G., Reith, F., 2014. In situ recovery of uranium- the microbial influence. Hydrometallurgy 150, 236-244.

Zielinski, R.A., Otton, J.K., Schumann, R.R., Wirt, L., 2008. Uranium in surface waters and sediments affected by historical mining in the Denver west 1:100.000 quadrangle, Colorado. U.S. Geol. Surv. Scien. Invest. Report 2007 (5), 246. 